\title{
Inter-comparison and performance evaluation of chemistry transport models over Indian region
}

\author{
Gaurav R. Govardhan ${ }^{\mathrm{a}, *}$, Ravi S. Nanjundiah ${ }^{\mathrm{a}, \mathrm{b}}$, S.K. Satheesh ${ }^{\mathrm{a}, \mathrm{b}}$, K. \\ Krishna Moorthy ${ }^{c}$, Toshihiko Takemura ${ }^{\mathrm{d}}$ \\ ${ }^{a}$ Centre for Atmospheric and Oceanic Sciences, Indian Institute of Science, Bengaluru, \\ India. \\ ${ }^{b}$ Divecha Centre for Climate Change, Indian Institute of Science, Bengaluru, India. \\ ${ }^{c}$ Indian Space Research Organization Headquarters, Bengaluru, India. \\ ${ }^{d}$ Research Institute for Applied Mechanics, Kyushu University, Fukuoka, Japan
}

\begin{abstract}
Aerosol loading over the South Asian region has the potential to affect the monsoon rainfall, Himalayan glaciers and regional air-quality, with implications for the billions in this region. While field campaigns and network observations provide primary data, they tend to be location/ season specific. Numerical models are useful to regionalize such location-specific data. Studies have shown that numerical models underestimate the aerosol scenario over the Indian region, mainly due to shortcomings related to meteorology and the emission inventories used. In this context, we have evaluated the performance of two such chemistry-transport models: WRF-Chem and SPRINTARS over an India-centric domain. The models differ in many aspects including physical domain, horizontal resolution,meteorological forcing and so on. etc. Despite these differences, both the models simulated similar spatial patterns of Black Carbon (BC) mass concentration, (with a spatial correlation of 0.9 with each other), and a reasonable estimates of its concentration, though both of them under-estimated vis-a-vis the observations. While the emissions are lower (higher) in SPRINTARS (WRF-Chem), overestimation of wind parameters in WRF-Chem caused the concentration to be similar in both models. Additionally, we quantified the underestimations of anthro-
\end{abstract}

* Corresponding Author-

Email-address: govardhang@caos.iisc.ernet.in

Contact Number: +91-9972604218 
pogenic $\mathrm{BC}$ emissions in the inventories used these two models and three other widely used emission inventories. Our analysis indicates that all these emission inventories underestimate the emissions of BC over India by a factor that ranges from 1.5 to 2.9. We have also studied the model simulations of aerosol optical depth over the Indian region. The models differ significantly in simulations of AOD, with WRF-Chem having a better agreement with satellite observations of AOD as far as the spatial pattern is concerned. It is important to note that in addition to $\mathrm{BC}$, dust can also contribute significantly to AOD. The models differ in simulations of the spatial pattern of mineral dust over the Indian region. We find that both meteorological forcing and emission formulation contribute to these differences. Since AOD is column integrated parameter, description of vertical profiles in both models, especially since elevated aerosol layers are often observed over Indian region, could be also a contributing factor. Additionally, differences in the prescription of the optical properties of $\mathrm{BC}$ between the models appear to affect the AOD simulations. We also compared simulation of sea-salt concentration in the two models and found that WRF-Chem underestimated its concentration vis-a-vis SPRINTARS. The differences in near-surface oceanic wind speeds appear to be the main source of this difference. In-spite of these differences, we note that there are similarities in their simulation of spatial patterns of various aerosol species (with each other and with observations) and hence models could be valuable tools for aerosol-related studies over the Indian region. Better estimation of emission inventories could improve aerosol-related simulations.

Keywords: WRF-Chem, SPRINTARS, BC, AOD, Dust

\section{Introduction}

Aerosols are tiny $\left(10^{-9} \mathrm{~m}-10^{-4} \mathrm{~m}\right)$ solid or liquid particles suspended in air. They are capable of affecting the Earth's radiation budget through direct (Haywood and Ramaswamy, 1998, Haywood and Boucher, 2000, Kaufman et al., 2002, Takemura et al., 2005, Yu et al., 2006, Myhre, 2009) and indirect (Twomey, 1977, Lohmann and Lesins, 2002, Lohmann and Feichter, 2005, Kiran et al., 2009) pathways, besides having severe effects on human health (Krzyzanowski et al., 2005, Janssen et al., 2011). The South Asian region is known to be a hot spot of natural as well as anthropogenic aerosols (Ramanathan et al., 2001, Lelieveld et al., 2001). There has been an in- 
creasing trend in AOD over this region (Porch et al., 2007, Ramachandran et al., 2012, Babu et al., 2013). Such an aerosol loading over the region is capable of altering the radiation budget and potentially offsetting the large scale monsoonal circulation, resulting in modification in the rainfall distribution over the region (Chakraborty et al., 2004, Ramanathan et al., 2005, Lau et al., 2006). Additionally, a few recent studies (Lau et al., 2010, Qian et al., 2011, Yasunari et al., 2010, Gautam et al., 2013) have shown that the build-up of high concentrations of absorbing aerosols over the Indo-Gangetic Plains (IGP) and the Himalayan foothills appears to cause a reduction in snow albedo and subsequent accelerated snow/ice melt in the Himalayas during the pre-monsoonal months. Combining models and measurements, Nair et al. (2013) have brought out the importance of BC deposits on Himalayan glaciers in impacting the radiation budget through snow albedo forcing. Understanding the similar effects of such aerosols on the regional climate and local air quality thus becomes very important. To understand the regional heterogeneity of the aerosols, the Indian Space Research Organisation (ISRO) under ISRO-GBP (Geosphere Biosphere Programme) has set up a network of surface observatories for the measurement of aerosol related properties under the ARFI (Aerosol Radiative Forcing over India) (Moorthy et al., 2009, Moorthy and Satheesh, 2011, Babu et al., 2013) project; has carried out aircraft and high altitude balloon measurement campaigns under the ICARB (Integrated Campaign for Aerosols, gases and Radiation Budget) (Moorthy et al., 2008, Babu et al., 2011) and RAWEX (Regional Aerosol Warming EXperiment) projects respectively. While such observational campaigns help us develop a strong understanding about the aerosol scenario over specific locations, the numerical simulations of aerosols bring out such information for a larger spatial domain. Aerosol model simulations play an instrumental role in understanding the effect of aerosols on regional weather and climate processes. Studies like Chakraborty et al. (2004), Ramanathan et al. (2005), Lau et al. (2006), Bollasina et al. (2011) etc. have employed aerosol simulating numerical models to examine the interaction between the aerosol burden over the south Asian region and the monsoonal rainfall over the region. However, while the use of models is essential to understand the climate implications, it is equally important to evaluate the model performances against the actual measurements. There have been a few recent efforts in this direction (Reddy et al., 2004, Chin et al., 2009, Ganguly et al., 2009, Henriksson et al., 2011, Goto et al., 2011, Kumar et al., 2011, 2012, Nair et al., 2012, Cherian et al., 2013, Moorthy et al., 2013, Sanap et al., 2014, Pan et al., 2015, Govardhan 
et al., 2015). Ganguly et al. (2009) have examined the performance of the online-aerosol model GFDL-AM2 over the Indian region. The model underestimated the total column AOD over the belt of IGP by a factor close to 6 and $\mathrm{BC}$ mass concentrations by a factor of 10. A study by Govardhan et al. (2015) with WRF-Chem shows that AOD and BC concentrations are underestimated by this model by a factor of 2 or more during the pre-monsoon and post-monsoon periods. They have identified over- estimation of boundary layer height, stronger winds and possible underestimation of emissions as causes for this underestimation. Their results are in agreement with those of Nair et al. (2012), Moorthy et al. (2013) who have evaluated the performance of RegCM4, GOCART and CHIMERE chemistry transport models over the Indian region in simulating the mass concentration of $\mathrm{BC}$ aerosols, and compared these with concurrent measurements. Recently, Pan et al. (2015), examined the performance of 7 chemistry transport models in simulating AOD and mass concentrations of different aerosol species over Indian region. They also found under-estimations in AOD and species mass concentration by the models vis-a-vis satellite and surface observations. They attributed such shortcomings in the model to the unrealistic inventory of biomass-burning emissions and simulations of RH within the models. All these point to the dire need for more such evaluations, primarily to improve the applicability of such models for regional and global studies.

Driven by the reasons above, in this paper, we evaluate the performance of WRF-Chem simulations over the Indian region with the concurrent simulation using another established global chemistry transport model viz. SPRINTARS. The 2 chemistry transport models differ in many aspects including a). Horizontal resolution, b). Physical domain, c). Meteorological formulation. SPRINTARS uses grid nudging technique and corrects its meteorological component by nudging it with NCEP-NCAR reanalysis dataset (generally considered a good proxy for actual observations) once every 6 hours. WRFChem on the other hand, does not nudge its meteorological fields with observations. The model simulated aerosol parameters like AOD and surface concentrations of $\mathrm{BC}$ are inter-compared and evaluated against the concurrent observational data from satellites, and ground based network measurements. We have attempted to understand the reasons behind similarities and the differences in model simulations of AOD and BC. Additionally, with the help of such inter-comparison and evaluation of model simulated BC, we have suggested quantitative modifications in the anthropogenic BC emissions 
inventories used in these models as well as in three other widely used emissions inventories, for the BC emissions over Indian region. Model-to-model comparisons of sea-salt and dust simulations are also done to examine the consistency between the models, especially in view of the absence of direct measurements of these species.

This paper is organised as follows- Model and simulation details are presented in section 2. Section 3 describes the various observational datasets used in this study. Results can be found in section 4 and conclusions are written in section 5 .

\section{Model and Simulation details}

\subsection{WRF-Chem}

The online chemistry transport model WRF-Chem used in this study has been developed at NOAA, National Oceanic and Atmospheric Administration. A detailed documentation of WRF is given in Skamarock et al. (2008). These simulations were done over the Indian region $\left(55^{0} \mathrm{E}-97^{0} \mathrm{E}, 1^{0} \mathrm{~N}-\right.$ $37^{0} \mathrm{~N}$ ), for 2 selected months, May 2011 (representative of the pre-monsoon season) and October 2011 (representative of the post-monsoon). Lambertconformal projections were used with $12 \mathrm{~km}$ horizontal resolution. Cloud microphysics was parameterized using the Thompson scheme (Thompson et al., 2004) while the Zhang-Mcfarlene scheme (Zhang and McFarlane, 1995) was employed for cumulus parameterization. The MYJ scheme (Janjić, 2002) was used to parameterize boundary layer processes, while surface processes were modelled using RUC-LSM (Smirnova et al., 1997, 2000). The RRTMG scheme (Mlawer et al., 1997) was used to compute long and shortwave radiation. The chemistry in these simulations was modelled using the MOZCART chemical mechanism option, which is an alliance between MOZART (Emmons et al., 2010) mechanisms for gas-phase chemistry and the GOCART bulk aerosol scheme (Chin et al., 2002) for aerosol phase chemistry, with the Fast-J photolysis scheme (Wild et al., 2000). The model considers the following aerosols species: BC1 (Hydrophobic), BC2 (Hydrophilic), OC1 (Hydrophobic), OC2 (Hydrophilic), Dust (5 bins: effective diameters from 0.5 to $8 \mathrm{~m}$ ), Sea-salts ( 4 bins: effective diameters from 0.1 to $7.5 \mathrm{~m}$ ) and sulfate. The model considers aerosol transport processes like emissions, advection, diffusion and deposition (dry and wet). The direct effects of the 
aerosols are taken into account by coupling the aerosol scheme with the radiation scheme. More details about WRF-Chem can be found in Grell et al. (2005).The Initial and boundary conditions (updated every 6 hours) for meteorological variables are taken from NCEP FNL (Final) Operational Global Analysis data, interpolated to model resolution. For chemistry, a global chemistry transport model MOZART 4 (Emmons et al., 2010) has been used for initial and boundary conditions.

We have used the standard emission pre-processor software PREP-CHEMSRC (version 1, Freitas et al. (2011)) for generating emissions of precursor gases and aerosols over our domain in WRF-Chem simulations. The software uses chemistry-emissions from three different emission inventories. The RETRO (Schultz et al., 2007) database is used for different greenhouse and precursor gases, EDGAR (Olivier et al., 1996) for emissions of CO, NO, $\mathrm{NH}_{3}$ and VOCs and the GOCART database (Chin et al., 2002) is used for generating emissions $\mathrm{OC}, \mathrm{BC}$ and $\mathrm{SO}_{2}$ over the region. This emissions database has been formulated by following the methodology descibed in Cooke et al. (1999).

\subsection{SPRINTARS}

SPRINTARS is a global chemistry transport model fully coupled with MIROC an AGCM. The meteorological fields of the MIROC are nudged with NCEP-NCAR reanalysis dataset once every 6 hours. In these simulations, SPRINTARS has been run with a horizontal resolution of $1.125^{0} \times$ $1.125^{0}$ globally. It considers the following aerosol species: BC, OC, Dust (6 bins : effective radius from 0.1 to $10 \mu \mathrm{m}$ ), Sea-salts (4 bins : effective radius from 0.1 to $10 \mu \mathrm{m}$ ) and sulfate. Aerosol Transport processes viz. emission, advection, diffusion, deposition (dry and wet) are included in the simulations. The direct and the indirect effects of the aerosols are incorporated in the model. Takemura et al. $(2000,2009)$ discuss SPRINTARS in detail. These simulations of SPRINTARS employed emissions from RCP 8.5 scenarios (Riahi et al., 2007) for anthropogenic sources and GFED3 (van der Werf et al., 2010) for biomass burning. The emissions of mineral dust, sea-salt and DMS are calculated online within the model framework. More details about the prescribed emissions in SPRINTARS can be found in Takemura (2012). The archived results from the model simulations of SPRINTARS are directly available at http://sprintars.riam.kyushu-u.ac.jp/archive.html., and 
the same have been used in this study.

\section{Observational Data}

\subsection{Surface Observations}

The Indian Space Research Organisation (ISRO) has set up a regional network (ARFINET) of several surface aerosol observation stations under the ISRO- Geosphere Biosphere Program (ISRO-GBP). These observatories measure near-real time mass concentrations of aerosol BC and other climatic parameters (Moorthy et al., 2009, Moorthy and Satheesh, 2011, Babu et al., 2013). In this study we compare model-simulated BC mass concentrations with the measurements from ARFINET network stations. We have used the data from 8 ARFINET stations: Bangalore (BLR), Chennai (CHN) and Trivandrum (TVM) from southern India; Hyderabad (HYD) and Ananthpur (ATP) from central-southern India; Ranchi (RNCH), Varanasi (VNS) and Delhi (DEL) from northern India. Fig.1 shows the locations of these observatories.

\subsection{Satellite data}

We have evaluated model simulated AOD by comparing it with that derived from MODIS (Moderate Resolution Imaging Spectroradiometer) and MISR (Multiangle Imaging Spectroradiometer) satellite AOD products. For MODIS, we have used the mean of the following level 3 products:- AOD at $550 \mathrm{~nm}$ from TERRA, AOD at $550 \mathrm{~nm}$ from Aqua and Deep blue AOD from Aqua (Deep blue from TERRA is not available for simulation periods), while for MISR, we have used level 3 product of AOD at 555nm from TERRA . MODIS AOD data has horizontal resolution of $1^{0} \times 1^{0}$ while MISR has a spatial resolution of $0.5^{0} \times 0.5^{0}$. The comparisons are done for the monthly mean spatial patterns of AOD during May and October 2011.

\section{Results and Discussions}

\subsection{Black Carbon (BC)}

$\mathrm{BC}$ aerosols assume critical importance over the south Asian region, as the region is considered to be a global hot-spot of $\mathrm{BC}$ aerosols. Previous 


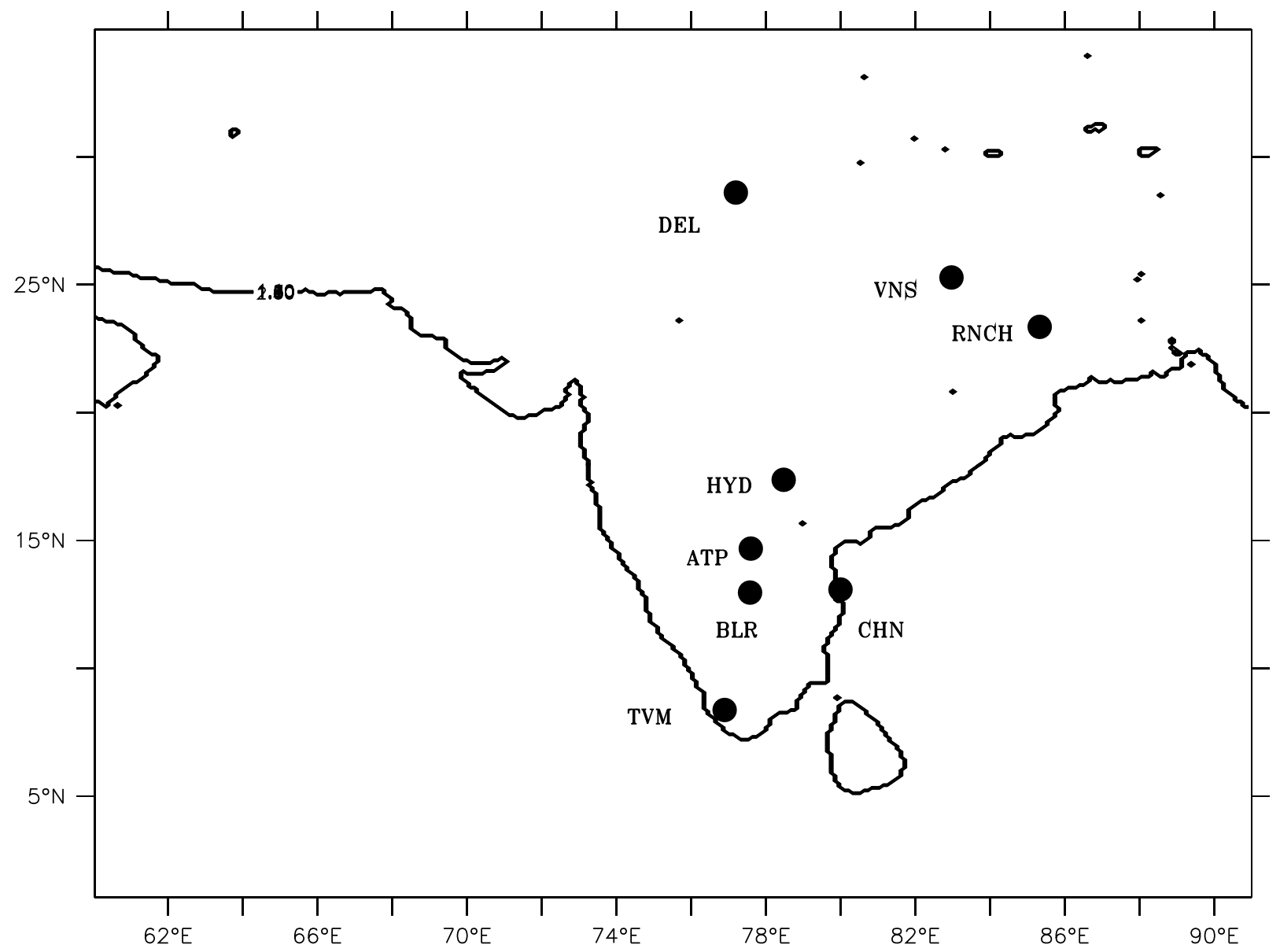

Figure 1: Surface observatories under ARFI network used in this study for measurement of $\mathrm{BC}$ mass concentrations. 
studies indicate that simulations of $\mathrm{BC}$ over this region could be affected by shortcomings in model simulated meteorology and emissions' inventories. Here we inter-compare and evaluate the simulated near-surface $\mathrm{BC}$ over the region in the two chemistry transport models which differ in many aspects. We attempt to understand the reasons behind similarities and differences in the model simulated BC.

\subsubsection{Model vs Observations}

A comparison of model simulations and observed near-surface BC mass concentrations has been carried out with ARFINET data from observatories at representative locations over India (Moorthy et al., 2009, Moorthy and Satheesh, 2011). The comparisons are done using data at following 8 stations- Bangalore $\left(12.96^{0} \mathrm{~N}, 77.58^{0} \mathrm{E}\right)$, Chennai $\left(13.08^{0} \mathrm{~N}, 80.27^{0} \mathrm{E}\right)$, Hyderabad $\left(17.37^{0} \mathrm{~N}, 78.48^{0} \mathrm{E}\right)$, Trivandrum $\left(8.37^{0} \mathrm{~N}, 76.9^{\circ} \mathrm{E}\right)$, Ananthpur $\left(14.68^{0} \mathrm{~N}\right.$, $\left.77.60^{\circ} \mathrm{E}\right)$, Varanasi $\left(25.28^{0} \mathrm{~N}, 82.97^{0} \mathrm{E}\right)$, Ranchi $\left(23.35^{\circ} \mathrm{N}, 85.33^{\circ} \mathrm{E}\right)$ and Delhi $\left(28.60^{\circ} \mathrm{N}, 77.20^{\circ} \mathrm{E}\right)$ (Fig.1). This set of stations represents a mixture of urban and semi-urban locations across India. Fig.2 shows the comparison between the daily mean BC near-surface mass concentrations from the models and observations, for the experimental period under consideration. The red dots show comparison between WRF-Chem and observations while the blue dots show such a comparison between SPRINTARS and observations.

Both the models underestimate Near-Surface BC mass concentrations (NSBC) vis-a-vis observations across all the measurement stations. The underestimation is larger over Chennai, Trivandrum, Varanasi and Delhi. Additionally, the models underestimate BC over the coastal stations like Chennai and Trivandrum by a larger margin, than that over the in-land stations. The BC underestimation by the models is quantified using a parameter known as Adjustment Factor (AF), which is the ratio of the observed value of $\mathrm{BC}$ mass concentration to the model-simulated value. So, by definition, higher the value of $\mathrm{AF}$, higher is the magnitude of underestimation by the model.The AF for WRF-Chem is written in red text, while that for SPRINTARS is written in blue text.It appears that the AF varies from location to location. Additionally, over in-land stations like Bangalore, Hyderabad, Anantpur, Varanasi, Ranchi and Delhi, WRF-Chem exhibits higher values of the AF vis-a-vis SPRINTARS, whereas over coastal stations SPRINTARS yields a higher AF. It may be noted that, even the model which employs realistic meteorological parameters (SPRINTARS) also underestimates the NSBC vis-a-vis observations. Also, it can be seen that, the model simulated 


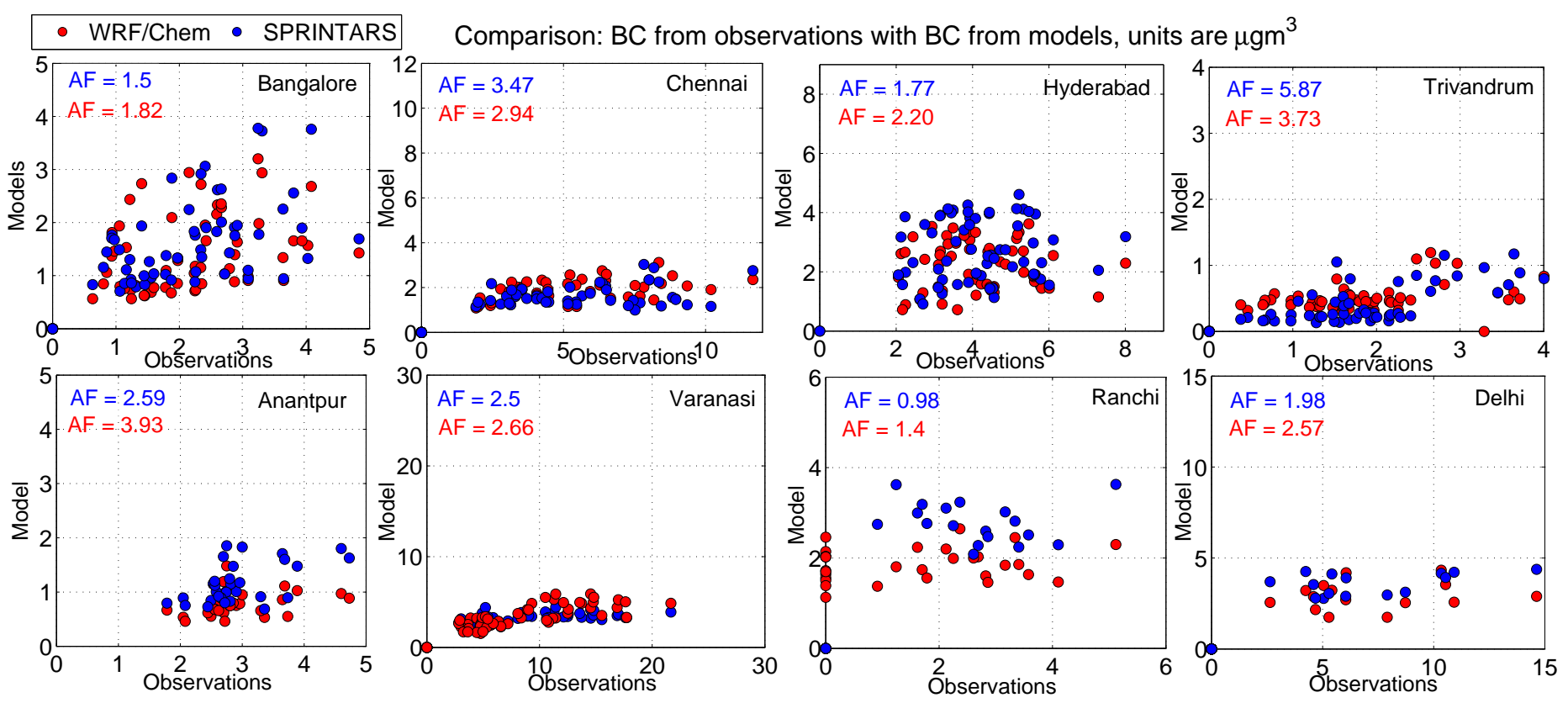

Figure 2: Comparison of model simulated BC with ARFINET daily observational data, for both the months . 
$\mathrm{BC}$ do not differ significantly with respect to each other and both of them largely underestimate the observations by similar margins, despite the overall differences in the modelling frameworks. To throw more light on this, we inter-compare the model simulated BC in the next section.

\subsubsection{WRF-Chem vs SPRINTARS BC Simulations}

Given the similarities in the model simulated NSBC over the observation locations, we here compare the model simulated NSBC over the entire Indian region in Fig.3. The panels $3 \mathrm{a}$ and $3 \mathrm{c}$ show the regional distribution of simulated NSBC during May 2011, by WRF-Chem and SPRINTARS respectively. The panels $3 \mathrm{~b}$ and $3 \mathrm{~d}$, present the corresponding scenarios during October 2011. During May 2011, WRF-Chem (Fig.3a) captured the regional $\mathrm{BC}$ hot-spot over the IGP region with BC magnitudes going up to 3.5-4 $\mu \mathrm{g}$ $\mathrm{m}^{-3}$. The BC maxima occurs over eastern polluted regions like Bengal and north-east India, with magnitudes reaching $4.5 \mu \mathrm{g} \mathrm{m}^{-3}$. The eastern part of India depicts a higher loading of BC (1-2 $\left.\mu \mathrm{g} \mathrm{m}^{-3}\right)$ vis-a-vis the western part (less than $0.5 \mu \mathrm{g} \mathrm{m}^{-3}$ ). Such a gradient would partly be due to the differences in magnitude of $\mathrm{BC}$ emissions over these regions and also due to the direction of prevailing winds over the Indian landmass. The low level wind over the Indian region during the pre-monsoon season are predominantly westerlies and those transport the particulates towards the eastern side of India. This causes the Arabian-Sea (AS) to have a lower BC loading in WRF-Chem simulations (Fig.3a), while the Bay of Bengal (BoB) faces a continental BC transport near the coasts of the southern-central parts of India, with BC near-surface values going upto $0.5-1 \mu \mathrm{g} \mathrm{m}^{-3}$. During the same month, SPRINTARS (Fig.3c) also exhibits a regional BC hot-spot over the GP belt, with $\mathrm{BC}$ values reaching upto $4-4.5 \mu \mathrm{g} \mathrm{m}^{-3}$. A similar eastwest gradient in surface BC mass concentrations is also seen in SPRINTARS simulations for the month of May 2011. A similar continental transport of $\mathrm{BC}$ into BoB is simulated by SPRINTARS, but it extended slightly farther into the Bay. In general, the spatial patterns of simulated near-surface BC mass concentrations from both the models were in good agreement with the pre-monsoon month, with a spatial correlation coefficient of 0.92 . 


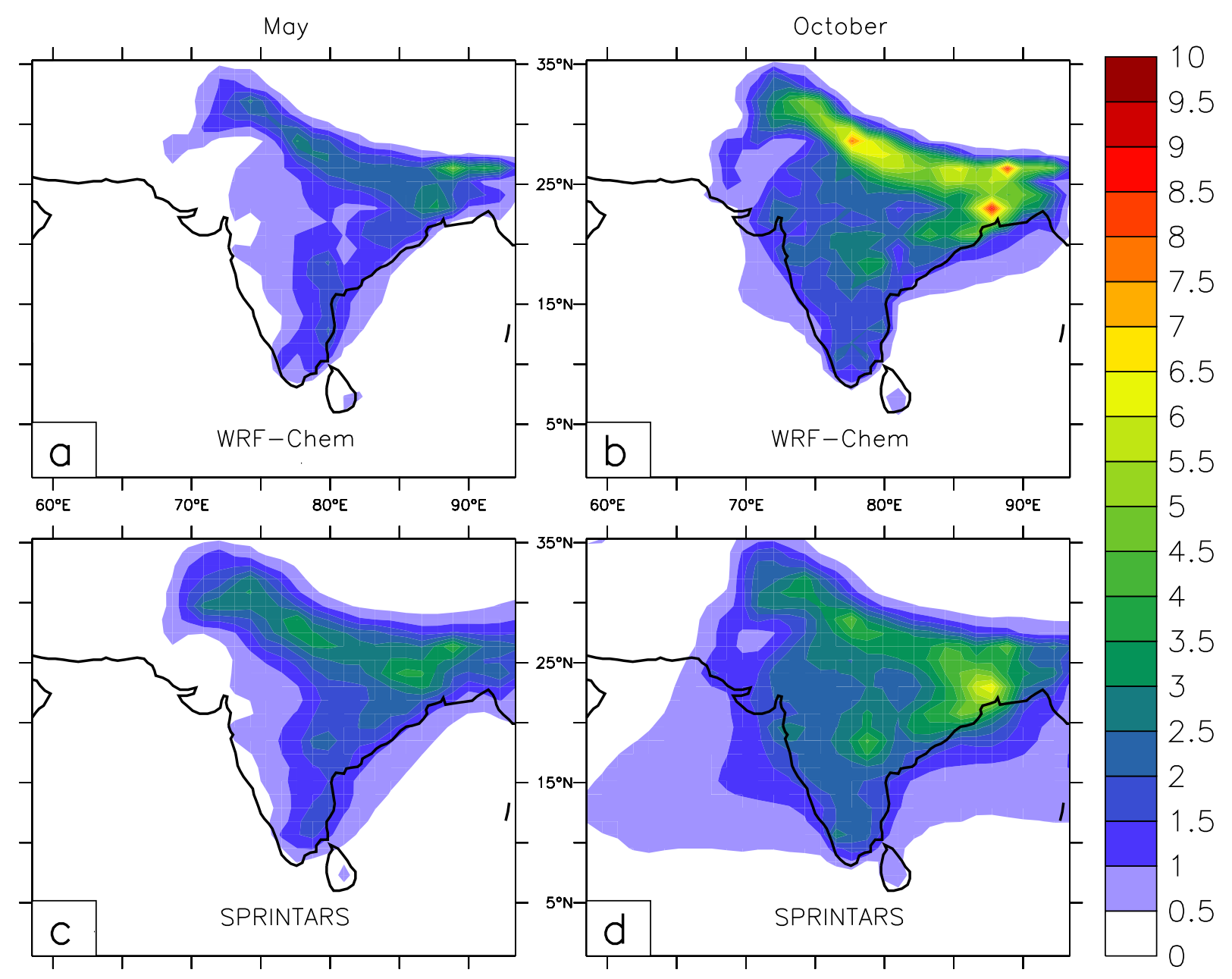

Figure 3: Comparison of model-simulated near-surface BC mass concentration $\left(\mu \mathrm{g} \mathrm{m}^{-3}\right)$ over Indian region for both the months 
During the post-monsoon month of October 2011, the near-surface BC mass concentration is in-general higher vis-a-vis May mainly due to convectively stable atmospheric conditions, which inhibit the vertical transport of surface BC (which was active during May) and confine the particulates to the lower atmospheric levels (Fig.6, Govardhan et al. (2015)). In WRF-Chem simulations (Fig.3b), this increases the BC loading over regional hot-spots like IGP to reach an average value of $6-7 \mu \mathrm{g} \mathrm{m}^{-3}$ (from $3 \mu \mathrm{g} \mathrm{m}^{-3}$ in premonsoon season), with local maxima (Delhi, Bengal coast and some spots in north-east) higher than 8.5-9 $\mu \mathrm{g} \mathrm{m}^{-3}$ (Fig.3b). The central Indian region shows a BC near-surface loading of around $4 \mu \mathrm{g} \mathrm{m}^{-3}$, while that over Southern India is seen to be around $1-2 \mu \mathrm{g} \mathrm{m} \mathrm{m}^{-3}$. The east-west gradient in surface BC concentrations during the pre-monsoon season (Fig.3a and Fig.3c) decreases significantly during the post-monsoon season due to the reversed direction of low levels winds. The oceanic bodies also experience increments in $\mathrm{BC}$ loading (Fig.3b). Post monsoon, the regions adjacent to the western coast line of India (BC upto $1 \mu \mathrm{g} \mathrm{m}^{-3}$ ) face an outflow of BC from western India due to the prevailing winds from the interior. Such an outflow of $\mathrm{BC}$ is also seen over the northern part of the $\mathrm{BoB}\left(\mathrm{BC}: 1-1.5 \mu \mathrm{g} \mathrm{m}^{-3}\right.$ ), which happens to receive it from IGP. SPRINTARS simulations for the same month (Fig.3d) also show an increase in near-surface BC values. A familiar $\mathrm{BC}$ hot-spot over GP is seen with values reaching upto $4-5 \mu \mathrm{g} \mathrm{m}^{-3}$, with a maxima over coastal regions of Bengal (BC : $6 \mu \mathrm{g} \mathrm{m}^{-3}$ ), in SPRINTARS. The rest of the landmass (CI: $3.5-4 \mu \mathrm{g} \mathrm{m}^{-3}$, SI: $2-3 \mu \mathrm{g} \mathrm{m}^{-3}$ ) is seen to be under relatively lower BC surface loading. Similar to WRF-Chem, SPRINTARS also depicts the transport of the continental BC mass into the surrounding water bodies around India during the post-monsoon season. The AS has a $\mathrm{BC}$ loading of 0.5 to $1.5 \mu \mathrm{g} \mathrm{m}^{-3}$ with maxima occurring near the coast and the transport of $\mathrm{BC}$ extending up to $60^{\circ} \mathrm{E}$. The $\mathrm{BoB}$ also has a higher $\mathrm{BC}$ loading vis-a-vis May (Fig.3c) with maxima around the northern part of the Bay, with values ranging from 0.5 to $1.5 \mu \mathrm{g} \mathrm{m}^{-3}$. For both the water basins, SPRINTARS shows a farther transport of BC vis-a-vis WRF-Chem owing to its coarser horizontal resolution. As in May, during October too we found that the simulated patterns were similar with a spatial correlation of 0.91 .

\subsubsection{Quantification of differences (Model-Model)}

In this section we quantify the similarities/differences in model simulations of NSBC over the complete domain. Scaling Factor-BC (SF-BC, which is the ratio of magnitude of the simulated BC in SPRINTARS to that in 
WRF-Chem) is used to quantify the similarities and differences. So, the higher the value of SF-BC, the higher is the underestimation of BC in WRFChem vis-a-vis SPRINTARS. Such SF-BCs are averaged over 9 specific regional boxes (Fig.4) spanning the entire domain, for both the months (Table $1)$.

The boxes are so chosen that all of them individually capture regions with some peculiar features, while together, they cover the main critical regions. It may be noted that for May (Table 1, column 2), WRF-Chem shows better comparison with SPRINTARS over the land (grid boxes like NIGP, Bengal, CI, SI and LNAS) as compared to that over oceans. Over most the land regions, SF-BC values are closer to 1, showing a relatively lesser underestimation in WRF-Chem vis-a-vis SPRINTARS. Similarly during October 2011 (Table 1, column 3), the land regions show better agreement between WRF-Chem and SPRINTARS vis-a-vis that over oceans. In-general, with a few exceptions, models show a satisfactory agreement in simulated BC mass concentrations over the Indian land-mass:-the home of BC emission sources. Thus, interestingly though the models SPRINTARS and WRF-Chem differ in many aspects, they show some kind of an agreement in the simulated $\mathrm{BC}$ mass concentrations. To understand this further, we next examine the emission scenarios used in these models.

Table 1: Ratio of model simulated BC (SPRINTARS BC/WRF-Chem BC) during May and October 2011

\begin{tabular}{|l|l|l|}
\hline Region & May & Oct \\
\hline NIGP & 1.5 & 0.85 \\
\hline Bengal & 1.19 & 0.77 \\
\hline CI & 1.39 & 1.18 \\
\hline SI & 1.11 & 1.2 \\
\hline NW & 2.04 & 1.41 \\
\hline LNAS & 1.39 & 1.75 \\
\hline BoB & 1.45 & 4 \\
\hline HBoB & 1.56 & 1.64 \\
\hline AS & 1.67 & 2.5 \\
\hline NAS & 1.92 & 2.63 \\
\hline
\end{tabular}




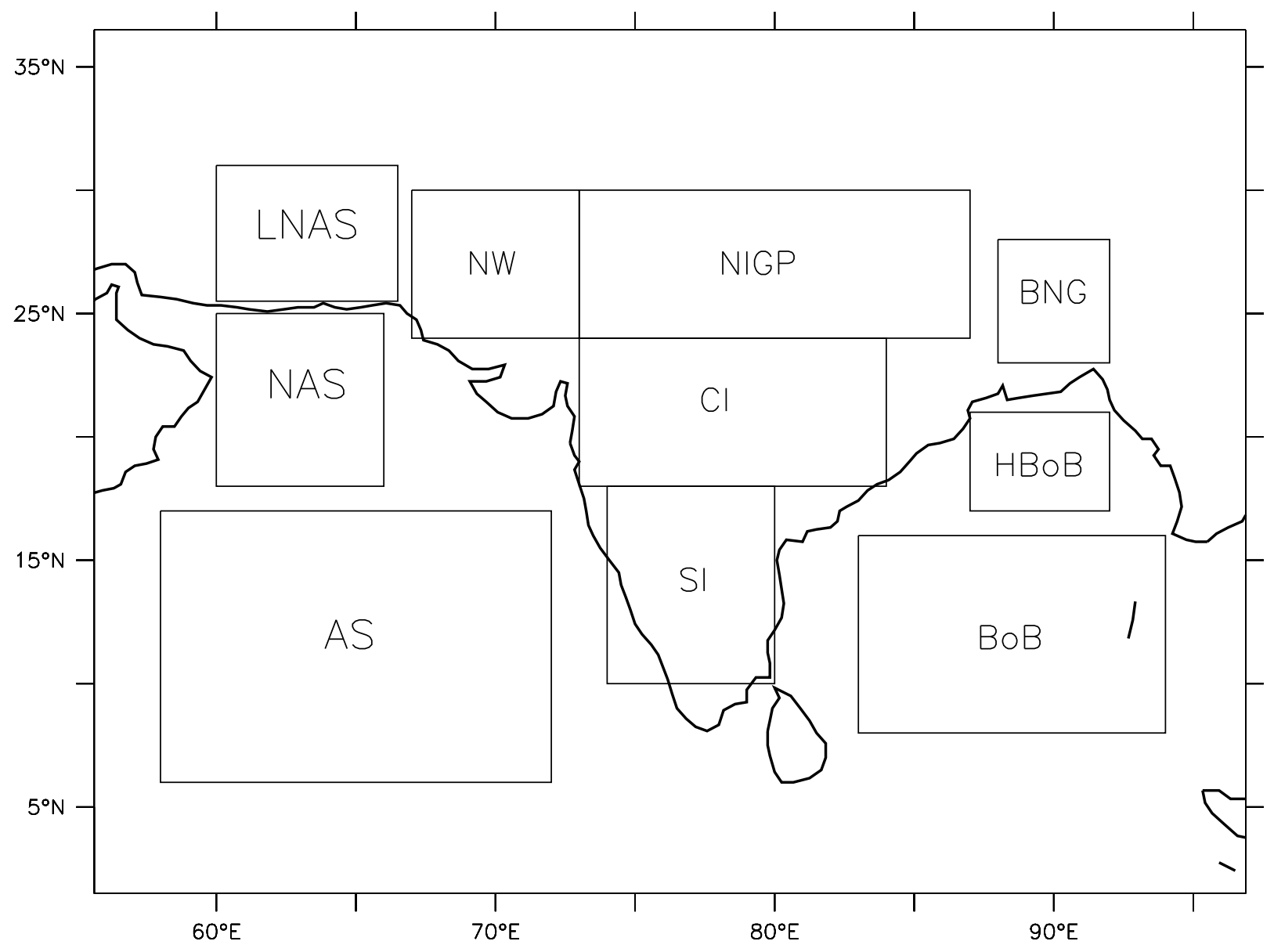

Figure 4: Regional boxes used in calculation of AF for different species. Box BNG is only used in AF for BC analysis. LNAS- Landmass North of Arabian Sea, NW- North-Western part of Indian subcontinent, NIGP- Northern India along with Gangetic Plains, BNGBengal, CI- Central India, SI- Southern India, NAS- Northern part of Arabian Sea, ASArabian Sea, HBoB- Head part of Bay of Bengal, BoB- Bay of Bengal 
Table 2: Comparison between GOCART and RCP8.5 emissions scenarios, and WRF-Chem and SPRINTARS BC over the observational stations viz. BLR-Bengaluru, CHN-Chennai, TVM-Trivandrum, ANT-Anantpur, HYD-Hyderabad, DEL-Delhi, VNS-Varanasi and RNCH- Ranchi.

\begin{tabular}{|l|l|l|l|l|}
\hline Location & $\begin{array}{l}\text { GOCART/ } \\
\text { RCP8.5 emissions }\end{array}$ & $\begin{array}{l}\text { WRF-Chem BC/ } \\
\text { SPRINTARS BC }\end{array}$ & $\begin{array}{l}\text { Observed BC / } \\
\text { WRF-Chem BC }\end{array}$ & $\begin{array}{l}\text { Observed BC/ } \\
\text { SPRINTARS BC }\end{array}$ \\
\hline BLR & 1.53 & 0.87 & 1.59 & 1.38 \\
\hline CHN & 2.03 & 1.15 & 2.88 & 3.3 \\
\hline TVM & 1.25 & 1.25 & 3.71 & 4.64 \\
\hline HYD & 1.55 & 0.81 & 1.88 & 1.52 \\
\hline ANT & 1.62 & 0.69 & 3.71 & 2.55 \\
\hline DEL & 1.39 & 0.82 & 2.44 & 1.98 \\
\hline VNS & 1.67 & 1.08 & 2.56 & 2.75 \\
\hline RNCH & 1.58 & 1.08 & 1.13 & 1.21 \\
\hline
\end{tabular}

4.1.4. BC emissions inventories: WRF-Chem vs SPRINTARS:

To understand the reasons behind agreements in simulated BC by WRFChem and SPRINTARS, we in this section, compare the anthropogenic BC emissions used in these 2 models. BC emissions used in WRF-Chem are from GOCART database. The emissions are prepared using a standard WRFChem utility prep_chem_sources. SPRINTARS on the other hand uses BC emissions from RCP 8.5 (Riahi et al., 2007) concentrations scenario. The emission inventories exhibit a spatial correlation coefficient of 0.97 . This indicates that, both the models (WRF-Chem and SPRINTARS) employ similar spatial map of $\mathrm{BC}$ emissions. This could be one of the reasons behind very high spatial correlation between model simulated BC. We next compare the emission magnitudes in these 2 emission inventories over the observation locations, in table 2.

Along with emission comparisons, we have also shown the comparisons between simulated $\mathrm{BC}$ and measured $\mathrm{BC}$ over the station. It may be noted from table 2 that, though the models differ in magnitudes of prescribed $\mathrm{BC}$ emissions (Column 2, table 2), the differences in the simulated BC mass concentrations (Column 2, table 2) are always within $\pm 20 \%$ (except for Anantpur). Also, both the models underestimate the observations largely by similar margins (Column 4 and Column 5, table 2). Nevertheless, it is seen that, over the urban stations like Bengaluru, Hyderabad, Chennai, 
Table 3: Comparison between $850 \mathrm{hpa}$ wind speeds in WRF-Chem, SPRINTARS and MERRA over the 10 regional grid boxes

\begin{tabular}{|l|l|l|l|l|}
\hline Region & WRF-Chem/ MERRA & & SPRINTARS/MERRA & \\
\hline & May & October & May & October \\
\hline LNAS & 1.15 & 1.22 & 1.17 & 0.99 \\
\hline NW & 1.28 & 1.53 & 1.17 & 1.03 \\
\hline NIGP & 1.1 & 1.52 & 0.98 & 0.86 \\
\hline BNG & 1.29 & 1.86 & 1.03 & 0.82 \\
\hline CI & 1.39 & 1.17 & 0.98 & 0.95 \\
\hline SI & 1.52 & 1.6 & 0.7 & 1.1 \\
\hline NAS & 0.95 & 0.92 & 0.78 & 0.62 \\
\hline AS & 1.15 & 1.55 & 1.16 & 0.9 \\
\hline HBoB & 1.03 & 0.88 & 0.99 & 0.64 \\
\hline BoB & 1.52 & 0.88 & 0.9 & 0.97 \\
\hline
\end{tabular}

Varanasi, Ranchi and Delhi, as well as over the semi-urban station Anantpur the emissions in GOCART are higher than that in RCP 8.5 (Column 2, table 2), while the simulated concentrations are lower in WRF-Chem compared to SPRINTARS (Column 3, especially for Bengaluru, Hyderabad, Anantpur and Delhi). Even for other stations like Chennai, Varanasi and Ranchi, the WRF simulated concentrations are not significantly higher (as could be expected from the corresponding higher emission) than those by SPRINTARS. We next examine the possible role of meteorological parameters in governing this scenario.

\subsubsection{Simulated meteorological parameters: WRF-Chem vs SPRINTARS}

In the light of such agreements in the simulated near-surface BC massconcentrations in-spite of the different emissions magnitudes, we compare the simulated meteorological variables in the models. Simulations of low levels winds and boundary layer heights have a significant effect on simulations of near-surface BC mass concentrations (Govardhan et al., 2015). We here compare low-level (850 hpa) wind speeds in WRF-Chem with the reanalysis dataset MERRA. Same comparisons are done between SPRINTARS and MERRA as well (Table 3).

Such comparisons are done over the 10 regional boxes within the model domain (Fig.4). It can be seen that, WRF in-general overestimates 850 hpa wind-speeds vis-a-vis MERRA. Such overestimations of wind are higher in 
October vis-a-vis May over the land-only regions (LNAS to SI). SPRINTARS, on the other hand shows a good comparison with MERRA, with magnitude ratios being closer to 1 over most of the regional boxes within the domain, during May 2011. During October 2011, SPRINTARS underestimate wind speeds vis-a vis MERRA over a few regional boxes. Thus, WRF-Chem looks to overestimate winds speeds over the Indian region, while SPRINTARS does a slight underestimation. Since SPRINTARS is nudged with observations for the simulations meteorological parameters, we would thus expect such agreement between SPRINTARS simulated meteorological parameters and the observations. It is important to note that, near-surface wind affect the horizontal transport of pollutants within lower atmosphere. Thus higher the wind speeds, higher the transport of pollutants from their sources. This could reduce the concentrations of pollutants in the source regions. Low-level wind speeds and boundary layer heights affect simulations of $\mathrm{BC}$ over Indian region (Govardhan et al., 2015). We would have liked to compare boundary layer height simulations in WRF-Chem with SPRINTARS, but boundary layer height is not stored as an output variable in SPRINTARS simulations. Nevertheless, in a previous study Govardhan et al. (2015), we found that, WRF-Chem over estimates the boundary layer height over the region visa-vis MERRA. Thus it appears that, WRF-Chem overestimates meteorological parameters like low-level winds and boundary layer heights vis-a-vis MERRA and SPRINTARS simulations. The higher the low-level wind-speed and boundary layer heights the lower will be the near-surface concentration of BC (Govardhan et al., 2015). Thus, given that WRF-Chem prescribes higher BC emissions over the Indian region as compared to SPRINTARS, we would in-general expect that the simulated BC concentrations in WRF-Chem would also be higher. But due to overestimated meteorological parameters in WRF-Chem, it does an enhanced ventilation of surface BC mass and hence surface BC mass concentration reduces. Thus, the models WRF-Chem and SPRINTARS do not differ significantly in simulated BC mass concentrations due to the balance between overestimated meteorological variables in WRFChem and lower emissions of BC in SPRINTARS. Interestingly, we noticed that, even SPRINTARS, a model which employs realistic meteorology in its formulation, underestimates NSBC. In presence of realistic meteorological parameters, we would expect that, such an underestimation would be caused primarily due to an an underestimation in prescribed emissions of $\mathrm{BC}$ over the region. Thus, it seems that there is a possible low bias in the $\mathrm{BC}$ emissions inventory used by SPRINTARS model, which could give rise to such 
Table 4: Spatial correlation coefficient between GOCART, RCP8.5 and other inventories

\begin{tabular}{|l|l|l|l|}
\hline Inventory & CC with MACCity & CC with REAS & CC with SAFAR_India \\
\hline GOCART & 0.87 & 0.91 & 0.76 \\
\hline RCP 8.5 & 0.9 & 0.93 & 0.78 \\
\hline
\end{tabular}

underestimations of NSBC. In the next section, we attempt to quantify this low bias in BC emissions used in SPRINTARS.

\subsubsection{Comparison of BC emissions used in SPRINTARS and WRF-Chem with other emission inventories:}

In this section, we have compared RCP8.5 (BC emissions inventory used in SPRINTARS) and GOCART (BC emissions inventory used in WRFChem) with the globally widely used emission inventories viz. MACCity(Lamarque et al., 2010, Granier et al., 2011, Diehl et al., 2012), REAS(Ohara et al., 2007) and SAFAR_India (Sahu et al., 2008). Such comparisons are done for the period of May and October 2011, for which we have the model simulations. We have first examined the spatial match between the BC emission inventories used in the 2 models and the globally widely used emission inventories. The spatial correlation coefficient between the anthropogenic BC emissions in RCP 8.5, GOCART and that from the other inventories are listed in table 4.

It can be seen that, GOCART and RCP 8.5 have significantly high correlations $(\mathrm{P}<0.0001)$ with MACCity and REAS; but comparatively lesser correlation with SAFAR_India. Thus the spatial variation of all the 4 inventories are quite similar to each other, but they deviate somewhat from that of SAFAR_India. The SAFAR_India inventory has data only over India as it is generated from activity information about BC sources pertaining to India only. But, the other inventories have data over neighboring countries as well, and thus due to the lack of data in SAFAR_India inventory we get lesser spatial correlation of the other inventories with SAFAR_India. We then have done a magnitude-wise comparison of GOCART and RCP 8.5 with those inventories. Here we have taken ratios of area averaged BC emissions in GOCART and RCP8.5 inventories with that from the other emission inventories and the same are listed in table 5 . The spatial grid boxes chosen for this comparison are basically same as the ones used for BC spatial comparison between the models (Fig.4). We have selected only the land-only boxes out of those, for this comparison. 
Table 5: Ratio of BC emissions in GOCART and RCP8.5 inventories with the other inventories over 4 regional grid boxes

\begin{tabular}{|l|l|l|l|l|l|l|l|}
\hline Region & Lon,Lat & $\begin{array}{l}\text { GOCART/ } \\
\text { MACCity }\end{array}$ & $\begin{array}{l}\text { GOCART/ } \\
\text { REAS }\end{array}$ & $\begin{array}{l}\text { GOCART/ } \\
\text { SAFAR_India }\end{array}$ & $\begin{array}{l}\text { RCP8.5/ } \\
\text { MACCity }\end{array}$ & $\begin{array}{l}\text { RCP8.5/ } \\
\text { REAS }\end{array}$ & $\begin{array}{l}\text { RCP8.5/ } \\
\text { SAFAR_India }\end{array}$ \\
\hline NIGP & $\begin{array}{l}73^{0} \mathrm{E}: 87^{0} \mathrm{E}, \\
24^{0} \mathrm{~N}: 30^{0} \mathrm{~N}\end{array}$ & 1.43 & 1.13 & 0.83 & 0.91 & 0.72 & 0.53 \\
\hline Bengal & $\begin{array}{l}88^{0} \mathrm{E}: 92^{0} \mathrm{E}, \\
23^{0} \mathrm{~N}: 28^{0} \mathrm{~N}\end{array}$ & 2.07 & 0.96 & 1.85 & 1.3 & 0.6 & 1.15 \\
\hline CI & $\begin{array}{l}73^{0} \mathrm{E}: 84^{0} \mathrm{E}, \\
18^{0} \mathrm{~N}: 24^{0} \mathrm{~N}\end{array}$ & 1.96 & 1.17 & 1.02 & 1.18 & 0.71 & 0.62 \\
\hline SI & $\begin{array}{l}74^{0} \mathrm{E}: 80^{0} \mathrm{E}, \\
10^{0} \mathrm{~N}: 18^{0} \mathrm{~N}\end{array}$ & 1.94 & 1.22 & 1.07 & 1.17 & 0.74 & 0.65 \\
\hline
\end{tabular}

From Column 3-5, table 5 it can be seen that, GOCART inventory overestimates MACCity everywhere but is much closer to REAS and SAFAR_India inventories. In almost all cases, GOCART emissions inventory has higher emissions than the widely used inventories. On the other hand, the RCP8.5 scenario agrees fairly well with MACCity ( Column 6-8, Table 5); but strongly underestimates REAS and SAFAR_India over entire region. Thus overall, it can be said that, the BC emissions used in WRF-Chem i.e. GOCART emissions are comparable with the other widely use emission inventories, but that in SPRINTARS (RCP8.5) looks to underestimate vis-a-vis 2 of the 3 widely used inventories considered in this study. But, all the available emission inventories essentially provide estimates of the emissions and they have some uncertainties associated with them. So, it is possible that the widely used emission inventories like MACCity, REAS and SAFAR_India could have some uncertainties associated with them. So comparing RCP8.5 with the other widely used inventories will not give us a clear idea about a positive/negative bias in RCP8.5 with respect to reality. Nevertheless, in the next section we try to quantify this uncertainties in RCP $8.5 \mathrm{BC}$ emissions as well as other emission inventories used in this study.

\subsubsection{Quantification of emission underestimations in RCP 8.5, GOCART and other inventories:}

In general, the NSBC at a station bears a direct relationship with BC emissions occurring over the station. Thus we can write, 
Where,

NSBC $=$ Near-surface BC mass concentrations over a station

$\mathrm{E} \_\mathrm{BC}=\mathrm{BC}$ emissions over the station

Hence,

$$
N S B C=K(M e t) \times E_{\_} B C
$$

where,

$\mathrm{K}($ Met $)=\mathrm{A}$ constant which represents the effect of local meteorological conditions (low level wind speeds, boundary layer mixing, deposition etc.) on NSBC.

Extending (2) we can write, for station measurements of BC,

$$
N S B C_{o b s}=K(M e t)_{o b s} \times E_{-} B C_{\text {real }}
$$

and for SPRINTARS model simulations of NSBC

$$
N S B C_{S P I}=K(M e t)_{S P I} \times E_{-} B C_{S P I}
$$

where,

$\mathrm{NSBC}_{o b s}=$ Observed Near-surface BC mass concentration

$\mathrm{NSBC}_{S P I}=$ Simulated Near-surface BC mass concentration by SPRINTARS

$\mathrm{K}(\text { Met })_{o b s}=\mathrm{K}$ (Met) for observations

$\mathrm{K}(\text { Met })_{S P I}=\mathrm{K}$ (Met) for SPRINTARS

$\mathrm{E} \_B C_{\text {real }}=$ Real-life BC emissions over the observational station

$\mathrm{E} \_B C_{S P I}=\mathrm{BC}$ emissions in SPRINTARS simulation over the station

Taking ratios of (3) and (4),

$$
\frac{N S B C_{O b s}}{N S B C_{S P I}}=\frac{K(M e t)_{O b s} \times\left(E \_B C\right)_{\text {real }}}{K(M e t)_{S P I} \times\left(E \_B C\right)_{S P I}}
$$

Now, for SPRINTARS, the meteorological parameters are nudged with observations at every 6 hours. Hence, we could expect that, the simulated meteorological parameters in SPRINTARS would be realistic. 
Table 6: Multiplication factors by which the $\mathrm{BC}$ emissions in 5 different emission inventories are needed to be multiplied to match the $\mathrm{BC}$ emissions in reality, across the different observational stations viz. BLR-Bengaluru, CHN-Chennai, TVM-Trivandrum, ANT-Anantpur, HYD-Hyderabad, DEL-Delhi, VNS-Varanasi and RNCH- Ranchi.

\begin{tabular}{|l|l|l|l|l|l|}
\hline Station & MF_RCP8.5 & MF_MACC & MF_REAS & MF_SAF & MF_GOC \\
\hline BLR & 1.5 & 1.59 & 1.7 & 0.85 & 0.98 \\
\hline CHN & 3.47 & 4.27 & 2.22 & 1.84 & 1.71 \\
\hline TVM & 5.87 & 5.88 & 5.15 & 3.34 & 4.69 \\
\hline HYD & 1.77 & 2.85 & 1.56 & 1.43 & 1.14 \\
\hline ANT & 2.69 & 3.6 & 2.37 & 1.69 & 1.66 \\
\hline DEL & 1.98 & 1.43 & 1.69 & 0.63 & 1.42 \\
\hline VNS & 2.5 & 1.63 & 1.59 & 1.3 & 1.5 \\
\hline RNCH & 1.18 & 1.99 & 0.96 & 1.42 & 0.75 \\
\hline Mean & 2.62 & 2.91 & 2.15 & 1.56 & 1.73 \\
\hline
\end{tabular}

Hence,

$$
K(M e t)_{o b s}=K(M e t)_{S P I}
$$

Substituting (6) in (5) we get,

$$
E_{\_} B C_{\text {real }}=\frac{N S B C_{o b s}}{N S B C_{S P I}} \times E_{-} B C_{S P I}
$$

i.e.

$$
E_{\_} B C_{\text {real }}=M F_{\_} R C P 8.5 \times E_{\_} B C_{S P I}
$$

where,

MF_RCP8.5 $=\mathrm{NSBC}_{\text {obs }} / \mathrm{NSBC}_{S P I}=$ Multiplication Factor for RCP8.5, a factor by which $\mathrm{BC}$ emissions in RCP8.5 emissions inventory are needed to be multiplied to get close to the $\mathrm{BC}$ emissions in reality.

Thus, from (8) it can be seen that, to get the realistic BC emissions in SPRINTARS model (i.e. in RCP8.5 emissions inventory), we need to multiply the original emission magnitudes by a factor, MF_RCP8.5. Such MF_RCP8.5 values are computed for all the available observational stations in Table 6. Thus with the help of such MF_RCP8.5 values we attempt to quantify the discrepancy between the $\mathrm{BC}$ emissions in reality vis-a-vis BC emissions in RCP8.5 emission scenario. From column 2, Table 6, it can be that, in-general, MF_RCP8.5 values vary from station to station. It may be noted that, MF_RCP8.5 shows higher values over the coastal stations like 
Chennai (3.47) and Trivandrum (5.87). The mean values of MF_RCP8.5 comes out to be 2.62 , while that without considering the coastal stations comes out to be 1.94 .

Thus, if we multiply the RCP $8.5 \mathrm{BC}$ emissions by the station specific MF_RCP8.5, we would get the most realistic BC emissions at the particular station. Then the ratio of those most realistic $\mathrm{BC}$ emissions with $\mathrm{BC}$ emissions in the other inventories (e.g MACCity, REAS, SAFAR_India and GOCART) would give the quantification of the underestimation in BC emissions for those particular stations in India in these emission inventories. MF_MACC, MF_REAS, MF_SAF and MF_GOC respectively represent these underestimations for the various emission inventories under consideration. Thus, for a station, MF_MACC $=$ (Most realistic BC emissions / BC emissions in MACCity inventory) similarly, we can define MF_REAS, MF_SAF and MF_GOC. Largely, it can be seen that, all the emission inventories underestimate BC over coastal stations (Chennai and Trivandrum) by a large margin. The inventory SAFAR_India shows minimum MF values. MACCity inventory appears to be the one which needs a large multiplication factor to match the real-life $\mathrm{BC}$ emissions compared to the other inventories. Over most of the stations SAFAR_India and GOCART show good agreements. Thus, with this analysis, we have attempted to find out the underestimation for $\mathrm{BC}$ emissions in currently available, widely used emission inventories. In case of WRF-Chem, we notice that, the emission inventory for BC needs to be modified by factors which range from 0.75 to 4.69 depending upon the location. Also, such a quantification of $\mathrm{BC}$ emissions underestimation in WRF-Chem helps us understand role of other factors (simulations of meteorological parameters like low-levels winds and boundary layer heights) in affecting the $\mathrm{BC}$ underestimation in WRF-Chem. A similar comparison of multiple emissions inventories for anthropogenic $\mathrm{NO}_{x}$ emissions has also been carried out recently in Jena et al. (2015). They found that all those inventories overestimate the anthropogenic $\mathrm{NO}_{x}$ emissions over Indian region, mainly due to the errors in activity related data. 


\subsection{Aerosol Optical Depth (AOD)}

AOD is one of the most important parameters used in the assessment of climate impacts of aerosols. It represents the fraction of incident light (of any specific wavelength) scattered and absorbed by total column aerosol loading. Owing to its larger spatial coverage in comparison with station observations, we have compared model simulated AOD $(550 \mathrm{~nm})$ with that from MODIS and MISR satellite products, in-spite of known uncertainties (Kahn et al., 2007, Levy et al., 2010, Remer et al., 2005, Zhang et al., 2005).

\subsubsection{Uncertainties in satellite retrievals of $A O D$ :}

In-general, MODIS instrument on-board Terra and Aqua satellites, quote the following pre-launch uncertainties in the AOD values (King et al., 1999, Remer et al., 2005).

$\Delta \tau= \pm 0.05 \pm 0.15 \times \tau$ over land

$\Delta \tau= \pm 0.03 \pm 0.05 \times \tau$ over ocean where, $\tau=A O D$

There are many studies (Jethva et al., 2007b,a, Choudhry et al., 2012, More et al., 2013, Bibi et al., 2015, Misra et al., 2015) which have evaluated the MODIS and MISR retrieved AOD over location across India with the corresponding ground based measurements from AERONET network. All these studies highlight the limitations of satellite retrievals of AOD. The AOD retrieved using DeepBlue algorithm from MODIS instrument, in general underestimates stations measurements of AOD over different stations across India (More et al., 2013, Bibi et al., 2015, Misra et al., 2015). Nevertheless, satellites provide a regional picture of aerosol loading. Hence, despite certain issues with satellite estimates of AOD, we still use them to compare the models' performances; mainly due to their spatial coverage.

\subsubsection{Intercomparison and evaluation for May 2011}

An examination of satellite AOD products, namely, MODIS (Fig.5a) and MISR (Fig.5c) for the pre-monsoon month (May) over the simulation domain, reveals the following features a) a regional AOD hot-spot over the IGP and Sindh region (MODIS : 0.7-0.8, MISR : 0.6-0.7) b) higher AOD (upto 0.55) over the Eastern coast of India. c) moderate AOD (upto 0.60) over the rest of the Indian landmass d) an AOD east-west gradient across the Indian land mass with a higher AOD (upto 0.7) over the BoB and a relatively lower aerosol burden over AS (AOD : 0.45). e) the moderately loaded west coast of India with AOD that reaches upto 0.5. It can also be noted that, though the satellite products agree with each other over most 
parts of the study domain, they differ significantly over AOD hot-spots like IGP and Sindh. MODIS overestimates AOD over those regions vis-a-vis the MISR product.

For the same month, WRF-Chem (Fig.5e) shows an AOD hot-spot over the Gangetic plain (GP) region with AOD values ranging upto 0.4-0.45. Such a hot spot is a combined result of the abundance of high concentrations of anthropogenic aerosols (BC) over the densely populated belt (Fig.3a) and the seasonal transport of natural aerosols (mineral dust) due to the prevailing direction of the winds (Lau et al., 2006). Higher values of AOD (0.4-0.45) are also seen over the eastern coast of India, which could also be associated with anthropogenic aerosol mass over the belt (Fig.3a). Over the rest of the land mass of India, WRF-Chem shows a relatively lower aerosol burden with AOD ranging upto 0.2-0.3. Over the BoB, WRF-Chem exhibits a higher AOD (upto 0.4), which could be mainly attributed to the transport of the continental aerosol mass from the eastern-coast of India into the Bay, due to the direction of prevailing wind fields over the region during this season. WRF-Chem also simulates a higher AOD (upto 0.3) over the northern part of AS, which could be related to the transport of mineral dust from the region north-west of it. The rest of the AS has aerosol loading with an average AOD of about 0.15 . Of the 2 basins, the $\mathrm{BoB}$ is seen to have a larger burden of aerosol mass during the month of May, and this could be due to the advection of $\mathrm{BC}$ from the densely populated GP into the Bay. So, WRF-Chem successfully simulates the east-west gradient in AOD over the basins lying on either side of India.

For the same month, SPRINTARS (Fig.5g) exhibits a very high AOD over the semi arid region around Sindh with values reaching upto 1.3. The main cause for such a high AOD could be the presence of mineral dust aerosols over the region, which arise due to the drier conditions of the underlying surface. SPRINTARS also shows a secondary AOD hot-spot over the GP regions (AOD : 0.7), the possible causes for which could be an anthropogenic aerosol mass and/or mineral dust loading. The AOD over the rest of the Indian land mass in SPRINTARS is about 0.4-0.45. Over the BoB, SPRINTARS shows a lower AOD vis-a-vis WRF-Chem, with a mean value around 0.3 , and a spatial pattern similar to that of WRF-Chem (Fig.5e). Over the northern part of AS, SPRINTARS exhibits a higher AOD (average value of 0.55 ) the cause of which could be the heavy dust loading over the northern part of it. 
The AOD decreases away from the coast in the interior AS. In general the models are in better agreement in the simulation of AOD over the oceanic regions vis-a-vis land.

\subsubsection{Intercomparison and evaluation for October 2011}

A reduction in AOD during October 2011 was seen in both the satellite AOD products, MODIS (Fig.5b) and MISR (Fig.5d). Nevertheless, both the products exhibited a regional AOD hot-spot over GP with AOD values reaching upto 0.8 in MODIS and 0.7 in MISR. Over the rest of Indian land mass, also, satellite products show a reduction in AOD with a high AOD (0.5) over the southern peninsula, seen clearly in MODIS (Fig.5b). Over the BoB, both the products show moderate AOD values reaching upto 0.5, still lower than May. A peculiar spatial pattern of AOD is seen in both the products over AS with maxima (AOD : 0.45) occurring near the western coast of India.

During October 2011, in general, the aerosol burden over the entire domain decreases. Mineral dust dominates this aerosol blanket over the Indian region (on the basis of total mass) during pre-monsoonal months. Such a reduction in aerosol loading during October mainly occurs because of reduction in the mineral dust mass due to a) scavenging of the particulates by the monsoonal rainfall b) reduced dust emissions from the source region due to wetter surface conditions and c) absence of the assisting winds which cause dust influx into the Indian region during pre-monsoonal months. This reduction in AOD is well captured by both the models (WRF-Chem Fig.5f and SPRINTARS Fig.5h). WRF-Chem (Fig.5f) still exhibited an AOD hot-spot over IGP with values reaching upto 0.4 . The rest of the land mass was seen to be under a lower aerosol burden with the AOD around 0.2. The higher AOD over the BoB which prevailed during May (Fig.5e), decreases to a relatively lower value around 0.1. Such a large reduction in AOD was not seen over AS (except the northern part). The AOD over the central (0.15) and eastern parts (0.2) of AS was still comparable to that in May (Fig.5e), while a reduction in AOD was seen over the northern part of AS. During the same month, SPRINTARS simulations (Fig.5h) exhibited a very strong reduction in AOD vis-a-vis that in May (Fig. $5 \mathrm{~g}$ ). The AOD over the entire Indian land mass (except southern India and some parts of the eastern coast) decreased to very low values (0.1-0.2). The southern part of India was seen with a moderately high AOD upto 0.3 while that over the eastern-coast was seen to be around 0.25. Aerosol loading over the BoB completely decreased with an average value not exceeding 0.1. Nevertheless, such a large reduction in AOD was 


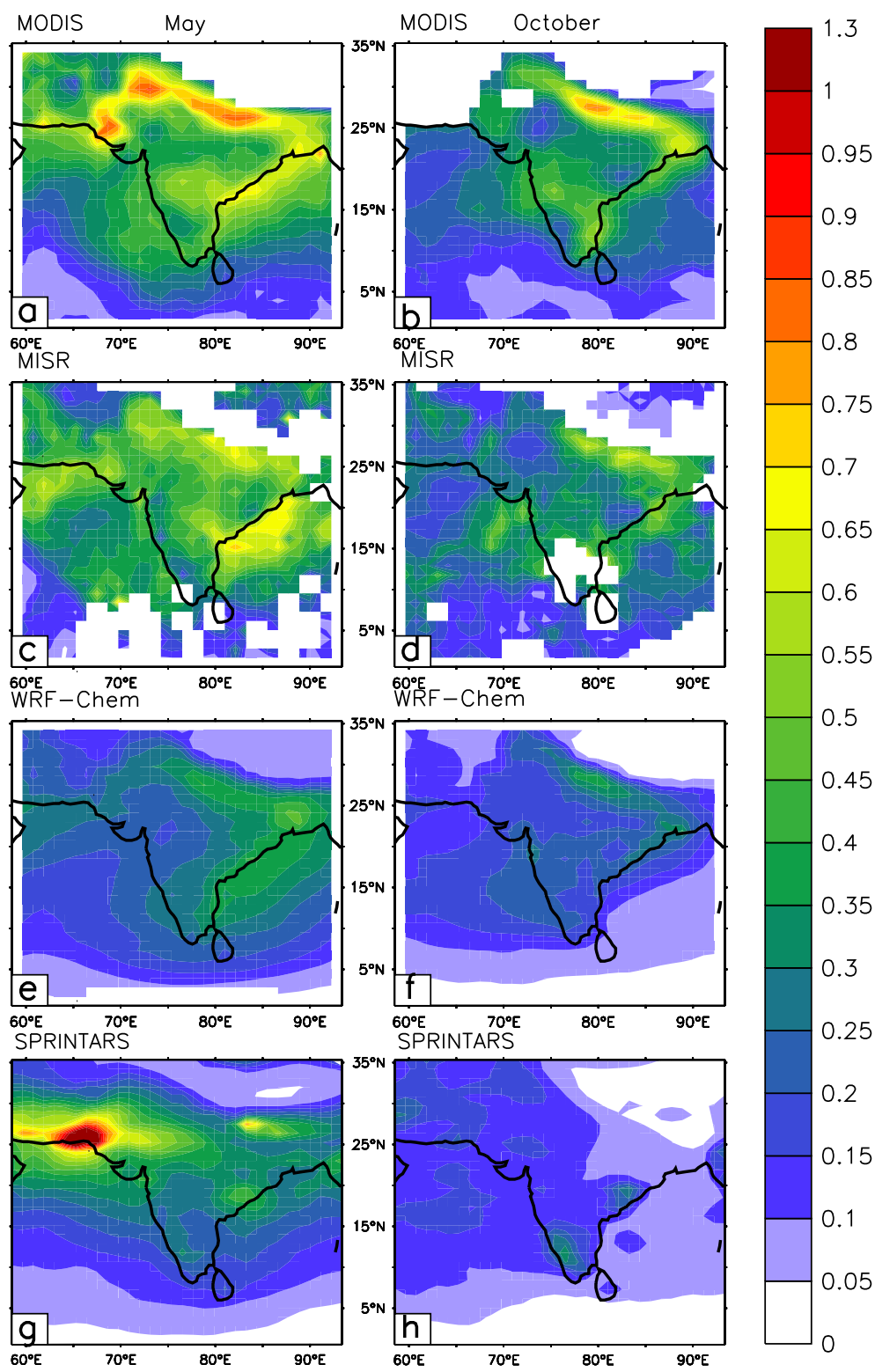

Figure 5: Monthly mean AOD (550nm) over Indian region for a)MODIS,May $2011 \mathrm{~b}$ ) MODIS, October 2011, c) MISR, May 2011 d) MISR, October 2011 e) WRF-Chem May 2011 f) WRF-Chem, October 2011 g) SPRINTARS, May 2011 h) SPRINTARS, October 2011 
not seen over AS (except the northern part), the average AOD over the entire AS attained an average AOD value upto 0.15. The AOD gradient switched its polarity vis-a-vis May, in both the model simulations (WRF-Chem Fig.5f and SPRINTARS Fig.5h) which was not that clearly seen in the satellite products (MODIS Fig.5b and MISR Fig.5d)

\subsubsection{Quantification of the AOD differences}

It can be clearly seen that both the models (WRF-Chem Fig.5e, Fig.5f and SPRINTARS Fig.5g, Fig.5h) underestimate the AOD vis-a-vis satellite products (MODIS Fig.5a, Fig.5b and MISR Fig.5c, Fig.5d) over the entire domain with a few exceptions. To quantify the AOD underestimation, we define a parameter 'Adjustment Factor AOD' (AF-AOD). AF-AOD is the ratio of the satellite AOD and the model AOD. We computed AF-AOD for 9 different regional boxes (Fig.4) of our complete domain and they are listed in Table 7 (for May 2011) and Table 8 (for October 2011). From the AF-AOD analysis for May (Table 7) it can be seen that, the WRF-Chem (Column 2 and 3) shows higher AF-AOD values vis-a-vis SPRINTARS, over the entire Indian landmass except SI for both the satellite products. WRFChem does maximum underestimation of the AOD over the LNAS, NW and NIGP regions (Avg. AF-AOD LNAS $=1.84, \mathrm{NW}=2.1, \mathrm{NIGP}=1.84$ ); which have large anthropogenic and natural aerosol loading. Over rest of the landmass it shows an average AF-AOD of 1.57. Over the oceans, WRFChem shows lower AF-AOD vis-a-vis SPRINTARS, with 1.66 over the AS and 1.55 over the BoB. On the other hand, SPRINTARS over LNAS and NW actually overestimates the AOD with an AF-AOD less than 1. Even over rest of the land mass, SPRINTARS shows a lower AF-AOD value (1.5) vis-a-vis WRF-Chem. Over the oceans, SPRINTARS underestimates AOD over most of the water-mass except NAS.

For October (Table 8), unlike for May, WRF-Chem (Column 2 and 3) has better simulations of AOD (with lower AF- AOD with both the satellite products), over the entire domain (land and oceans) vis-a-vis SPRINTARS (column 4 and 5). Over land, both the models show a higher AF-AOD in October vis-a-vis May. WRF-Chem shows a large AF-AOD over AOD hotspots like LNAS (2.03), NW (1.47) and NIGP (1.76), while over the rest of the landmass, it exhibits relatively lower AF-AOD (1.62). Over the BoB, both the models show a larger AF-AODs during October vis-a-vis May. WRFChem presents a mean AF-AOD of 2.78 over the entire BoB, and an AF-AOD of 1.46 over AS. For the same month, SPRINTARS (column 4 and 5), shows 
Table 7: Adjustment factor between models and satellite data, for May, 2011. AF= Satellite AOD / Model AOD

\begin{tabular}{|l|l|l|l|l|}
\hline Region & WRF-Chem & & SPRINTARS & \\
\hline & MODIS & MISR & MODIS & MISR \\
\hline Land & & & & \\
\hline LNAS & 1.93 & 1.75 & 0.68 & 0.62 \\
\hline NW & 2.38 & 1.824 & 1 & 0.77 \\
\hline NIGP & 1.9 & 1.79 & 1.524 & 1.44 \\
\hline CI & 1.64 & 1.61 & 1.3 & 1.29 \\
\hline SI & 1.63 & 1.41 & 1.88 & 1.63 \\
\hline & & & & \\
\hline Ocean & & & & \\
\hline NAS & 1.67 & 1.8 & 0.97 & 1.07 \\
\hline AS & 1.55 & 1.64 & 1.84 & 1.94 \\
\hline HBoB & 1.63 & 1.61 & 1.97 & 1.94 \\
\hline BoB & 1.34 & 1.47 & 1.95 & 2.14 \\
\hline
\end{tabular}

a very high AF-AOD over NIGP (3.85), relatively lower AFs over LNAS, $\mathrm{NW}$ and an average AF around 2.35 over the rest of the landmass. Over the oceans, SPRINTARS does a large underestimation with an AF-AOD of 4.1 over the BoB, but does simulate AOD better over AS with a relatively lower AF-AOD of 1.68. So, while both the models underestimate AOD vis-a-vis satellite observations, SPRINTARS has a lower AF-AOD during May and a very large AF-AODs during October. WRF-Chem has a comparable AFAOD during both the months and a lower AF-AOD vis-a-vis SPRINTARS during October.

Additionally, WRF-Chem shows a higher spatial correlation with the MODIS and MISR AOD spatial pattern than SPRINTARS (Table 9), for both months. It can also be seen that there are larger differences in models' spatial correlation coefficients with satellites for the month of October. SPRINTARS shows a very low correlation with satellite AOD products during October, while WRF-Chem replicates the pattern of satellite AOD during both months with significantly high correlation coefficients. So, WRF-Chem, while underestimating satellite AOD, mimics the AOD pattern significantly well. So, both models while underestimating AOD vis-a-vis satellite obser- 
Table 8: Adjustment factor between models and satellite data, for October, 2011. AF= Satellite AOD / Model AOD

\begin{tabular}{|l|l|l|l|l|}
\hline Region & WRFChem & & SPRINTARS & \\
\hline Land & MODIS & MISR & MODIS & MISR \\
\hline Sindh & NA & 2.03 & NA & 1.53 \\
\hline NW & NA & 1.47 & NA & 1.69 \\
\hline NIGP & 1.81 & 1.71 & 3.96 & 3.75 \\
\hline SI & 1.87 & NA & 2.34 & 2.17 \\
\hline CI & 1.52 & 1.46 & 2.49 & 2.4 \\
\hline & & & & \\
\hline Ocean & & & & \\
\hline NAS & 1.46 & 1.47 & 1.45 & 1.54 \\
\hline AS & 1.3 & 1.62 & 1.66 & 2.08 \\
\hline HboB & 2.19 & 2.07 & 5.13 & 4.86 \\
\hline BoB & 3.18 & 3.47 & 3.04 & 3.31 \\
\hline
\end{tabular}

Table 9: Spatial correlation between the AOD simulatd by the models and retrieved by the satellite products

\begin{tabular}{|l|l|l|l|l|}
\hline Model & Model and MISR & & Model and MODIS & \\
\hline & & & & \\
\hline & May & Oct & May & Oct \\
\hline & & & & \\
\hline SPRINTARS & 0.56 & 0.27 & 0.63 & 0.33 \\
\hline & & & & \\
\hline WRF-Chem & 0.78 & 0.71 & 0.82 & 0.81 \\
\hline
\end{tabular}

vations, significantly differ in simulating AOD over the Indian region. So, the similarities seen in model simulated patterns of BC completely disappear when model simulated AOD patterns are compared.

The possible cause for this difference between models could be related to the simulation of various aerosol species. We next examined the concentration of various aerosol species in order to determine the cause of these differences. Here, we have examined major natural aerosols present over the Indian region viz. dust and sea-salt. We additionally, re-examined the role of $\mathrm{BC}$ simulations from models in causing such differences in AOD distributions. 


\subsection{Mineral Dust}

We examined simulations of near-surface mineral dust mass concentrations over the entire study domain for May and October, using both the models (Fig.6). Near surface dust concentration is controlled by emission (related to wind speed, erodability and soil moisture), advection and deposition.

\subsubsection{Comparison of Dust simulations, during pre-monsoon}

During the pre-monsoonal month (May), WRF-Chem (Fig.6a) shows an in-flux of a large dust mass into the Indian region due to the action of prevailing surface winds in the dry and semi-arid regions of Arabia and the Sindh and Thar deserts. The main dust source region appears to be around the Thar desert with mass concentrations reaching as high as $400 \mu \mathrm{g} \mathrm{m}^{-3}$. Additionally, secondary sources are also seen over the deserts of Sindh and Arabia with average dust mass concentrations around $200 \mu \mathrm{g} \mathrm{m}^{-3}$. The entire Indian landmass (except North-east India) is seen to be affected by the dust inflow from these source regions. The regions closer to the dust sources (the Central and North-western part of India) show near-surface dust mass concentrations as high as $120 \mu \mathrm{g} \mathrm{m}^{-3}$, while those farther away from the sources show concentrations more than $30 \mu \mathrm{g} \mathrm{m} \mathrm{m}^{-3}$. Such a large dust mass is also seen over the oceanic part also, especially over the AS. The northern part of the sea bears a heavy dust cover with a dust mass concentration higher than $90 \mu \mathrm{g} \mathrm{m}^{-3}$, which is comparable to inland regions like the Central and North-western part of India. The central part of the AS experiences a relatively clearer atmosphere with lower dust mass concentrations (up to $30 \mu \mathrm{g} \mathrm{m}^{-3}$ ), as it is relatively distant from the dust source regions. For the same month, SPRINTARS (Fig.6c) also simulates heavy dust loading over most parts of the study domain. The main dust source in SPRINTARS simulations is seen to be around the Sindh region with a dust loading of more than $600-800 \mu \mathrm{g} \mathrm{m}^{-3}$, which is twice that over the WRF-Chem dust source. Such a heavy dust cover is seen to be spread across an area of $7^{0}$ long $\times$ $3^{0}$ lat. Additionally, secondary dust sources are seen to be over the Thar desert and GP with dust mass concentrations as high as 350-500 $\mu \mathrm{g} \mathrm{m}^{-3}$. Dust production from these source regions affects the entire northern part of India due to transport by the prevailing wind fields, resulting in dust mass concentrations around $90 \mu \mathrm{g} \mathrm{m}^{-3}$ near the source regions and $30-60 \mu \mathrm{g} \mathrm{m}^{-3}$ away from the source regions. The southern part of India in SPRINTARS simulations is seen to be relatively free from such a dust blanket. Most part 
of the oceanic regions of the study domain have a lower dust loading (less than $30 \mu \mathrm{g} \mathrm{m}^{-3}$ ) in SPRINTARS simulations, except the northern part of AS. This region, being close to the dust source region, is loaded with nearsurface dust with mass concentrations ranging from $30-90 \mu \mathrm{g} \mathrm{m}^{-3}$. Thus, during the pre-monsoonal month (May), though both the models simulate dust production over the desert regions and its advection into the rest of the Indian region, they differ in the details. While WRF-Chem (Fig.6a) shows a dust source around the Thar desert, SPRINTARS shows a more intense and larger dust source around the Sindh region. Also, the secondary dust source over GP in SPRINTARS is not seen in WRF-Chem simulations. Additionally, the magnitudes of dust mass concentrations over the dust sources in SPRINTARS are significantly higher vis-a-vis WRF-Chem. In addition to the differences in dust sources, the models also differ in simulating the transport of dust over the domain. WRF-Chem (Fig.6a) shows larger inland transport, with dust covering almost the entire Indian land-mass; in contrast, the transport is limited to central India in SPRINTARS (Fig.6c). Oceans are seen to be almost free from the dust blanket (except northern AS) in SPRINTARS (Fig.6c), while WRF-Chem exhibits a moderate dust loading over the central to northern part of AS.

\subsubsection{Comparison of Dust simulations, during post-monsoon}

For the post-monsoonal month (October), WRF-Chem (Fig.6b) and SPRINTARS (Fig.6d) simulate a reduction in the overall dust burden over the region, mainly attributed to the reduced production of dust aerosols due to damp surface conditions and the removal of atmospheric dust loading due to the monsoonal rainfall. Nevertheless, WRF-Chem (Fig.6b) still exhibits a dust source over the same regions (Thar, Sindh and Arabia) as seen in May (Fig.6a), though the magnitudes have almost decreased to $(1 / 4)^{t h}$ vis-a-vis May. The inland transport of dust also decreases with the magnitudes going down to $(1 / 3)^{r d}$ vis-a-vis May due to weaker and reversed wind fields during the post monsoon period compared to the pre monsoon. A similar reduction in dust is also seen over AS with concentrations going down to $(1 / 4)^{t h}$ that in May. For the same month, SPRINTARS (Fig.6d) shows a reduction in dust mass concentrations over the source regions (mainly Sindh and Arabia) by a factor close to 4-5 as compared to May (Fig.6c). The dust source over GP, which was active during May in SPRINTARS does not appear in the October simulations. SPRINTARS also simulates a reduction in the inland transport of dust into the Indian land-mass. The dust cover over AS also gets thinner 


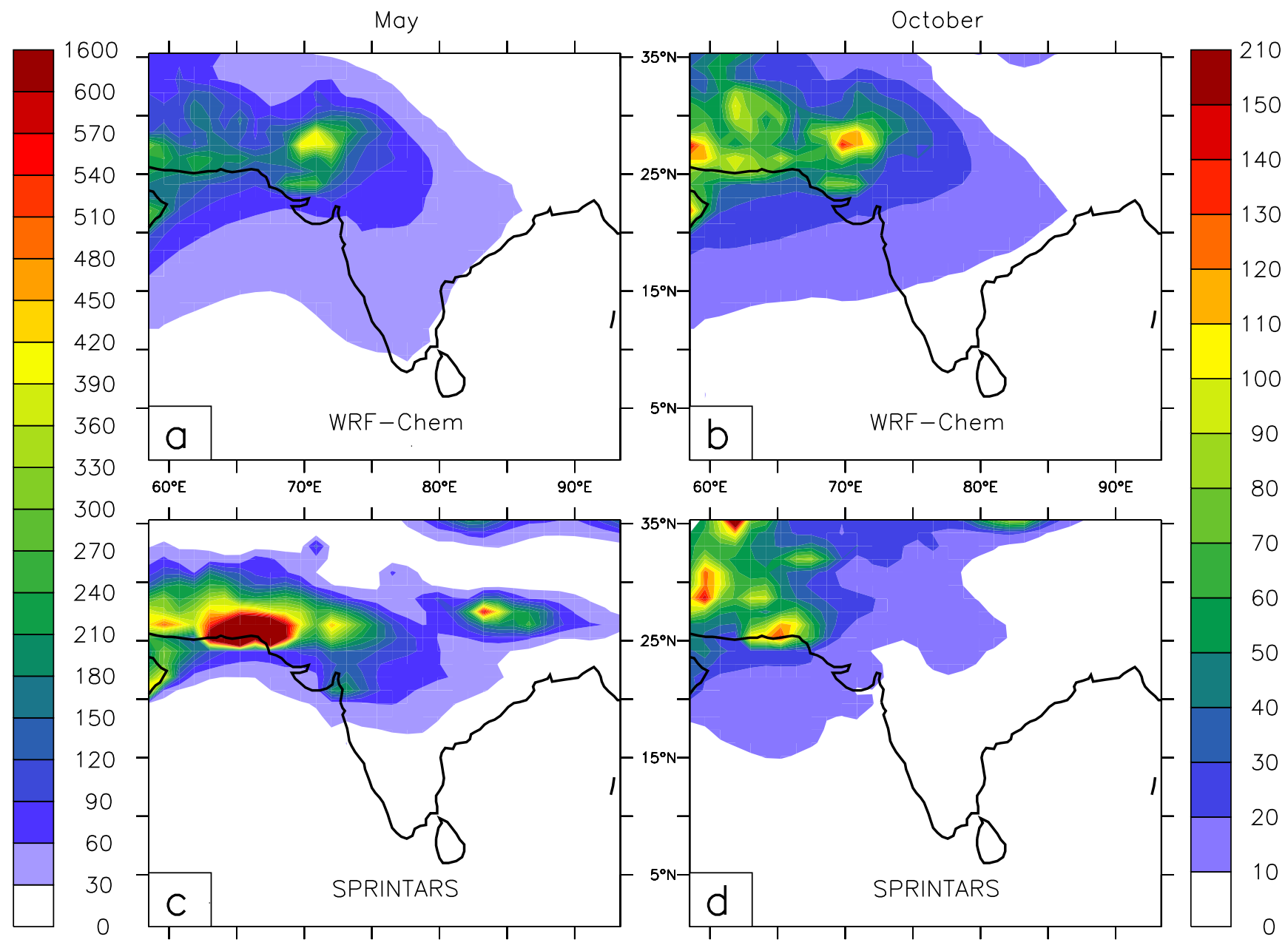

Figure 6: Comparison of model-simulated near-surface dust concentration $\left(\mu \mathrm{g} \mathrm{m}^{-3}\right)$ over Indian region for May and October 2011. Left colorbar should be read for May and right one should be read for October 
in October in SPRINTARS vis-a-vis May by a factor of 3 over the Northern AS. As in May, the models differ in simulating dust during October, also. The main differences in the model simulations of dust in October appear to be with the location of dust sources and the inland transport of dust.

\subsubsection{Quantification of dust differences}

To quantify such differences between model simulated near-surface dust mass concentrations, we computed the Scaling Factors (SF-Dust). Here, SF-Dust is the ratio of dust mass concentration in WRF-Chem to that in SPRINTARS. Please note the difference between SF-Dust used in this section and SF-BC used previously. SF-Dust for different locations is calculated for the same 9 regional boxes (Fig.4) and is presented in Table 10. It may be noted that for the month of heavy dust loading (May, column 2, Table 10), SPRINTARS exhibits a higher dust mass vis-a-vis WRF-Chem over most of the landmass (except SI) and over the northern part of AS, resulting in a SF-Dust lower than 1. Large differences are especially seen over regions of LNAS $(\mathrm{SF}=0.39)$ and NIGP $(\mathrm{SF}=0.56)$. The differences in modelled dust concentrations near the dust source locations (regions like LNAS, NW and NAS) could be related to the differences in the production of dust aerosols within the models, while that over the regions farther away (SI, BoB, HBoB and AS) could be related to the differences in the transport of dust aerosols within the models. For May, the models exhibit a SF-Dust lower than 1 over LNAS, NW and NAS. This points towards a possible higher production of dust aerosols in SPRINTARS vis-a-vis WRF-Chem. For the same month, the models exhibit SF-Dust greater than 1 over regions like AS, BOB, HBoB and SI, which hints at a weaker transport of dust in SPRINTARS vis-a-vis WRF-chem. So, it may be noted that, while SPRINTARS exhibits higher production of dust aerosol for May, it mimics a weaker transport of those aerosols away from the source region vis-a-vis WRF-Chem. For the month of October (Column 3, Table 10), WRF-Chem overestimates dust concentration over most of the domain (except LNAS). The models are in better agreement over the surrounding oceanic regions such as NAS, AS and BoB vis-a-vis the Indian landmass. Large differences are particularly noticeable over NW $(\mathrm{SF}-\mathrm{Dust}=2.62)$, due to a mismatch between model simulated dust source locations and CI (SF-Dust=2.14), SI $(\mathrm{SF}-D u s t=2.59)$, due to a subsequent lower inland transport of dust. 
Table 10: Scaling factor between models for dust during May and October 2011 SF-Dust= WRF Dust/SPRINTARS Dust

\begin{tabular}{|l|l|l|}
\hline Region & SF May & SF October \\
\hline Sindh & 0.39 & 0.97 \\
\hline NIGP & 0.56 & 1.84 \\
\hline NW & 0.69 & 2.62 \\
\hline CI & 0.85 & 2.14 \\
\hline SI & 1.9 & 2.59 \\
\hline NAS & 0.66 & 1.31 \\
\hline AS & 2.4 & 1.23 \\
\hline BoB & 2.19 & 1.53 \\
\hline HBoB & 2.58 & 3.34 \\
\hline
\end{tabular}

\subsubsection{Potential Causes of Discrepancy}

To understand the causes behind such differences between the dust simulations in the models, we first examined the formulation of the production of dust aerosols in both the models. Takemura et al. $(2000,2009)$ discuss the emission methodology employed in SPRINTARS, while WRF-Chem employs the dust emission model discussed in Ginoux et al. (2001). In general, dust particles become airborne due to the action of near-surface winds on the underlying surface. The particles get lifted up from the surface beyond a particular value of wind-speed, termed as the threshold wind speed. The rate of production of dust aerosols is directly related to wind magnitudes beyond the threshold wind-speed. Also, such a lifting of mineral dust particles from the surface is controlled by soil moisture. The higher Soil Moisture (SM) level, the lower is the lifting of particles from the surface and hence the lower is the production of dust aerosols. Both the models (WRF-Chem and SPRINTARS) propose these 2 criteria for dust emissions, but they differ in the details.

The models employ different threshold wind speeds $\left(\mathrm{U}_{t}\right)$ for the lifting of dust aerosols from the surface. SPRINTARS assumes a value of $6.5 \mathrm{~m}$ $\mathrm{s}^{-1}$ as the threshold wind speed $\left(\mathrm{U}_{t}\right)$, while WRF-Chem calculates $\mathrm{U}_{t}$ as a function of dust particle diameter, density and SM levels within the grid box. To understand the differences in these 2 dust emission models, we plotted the sensitivity of dust emissions in both the models to $10 \mathrm{~m}$ wind speeds $\left(\mathrm{U}_{10}\right)$ (Fig.7). In Fig.7 dust emission/production rates in the 2 models are 


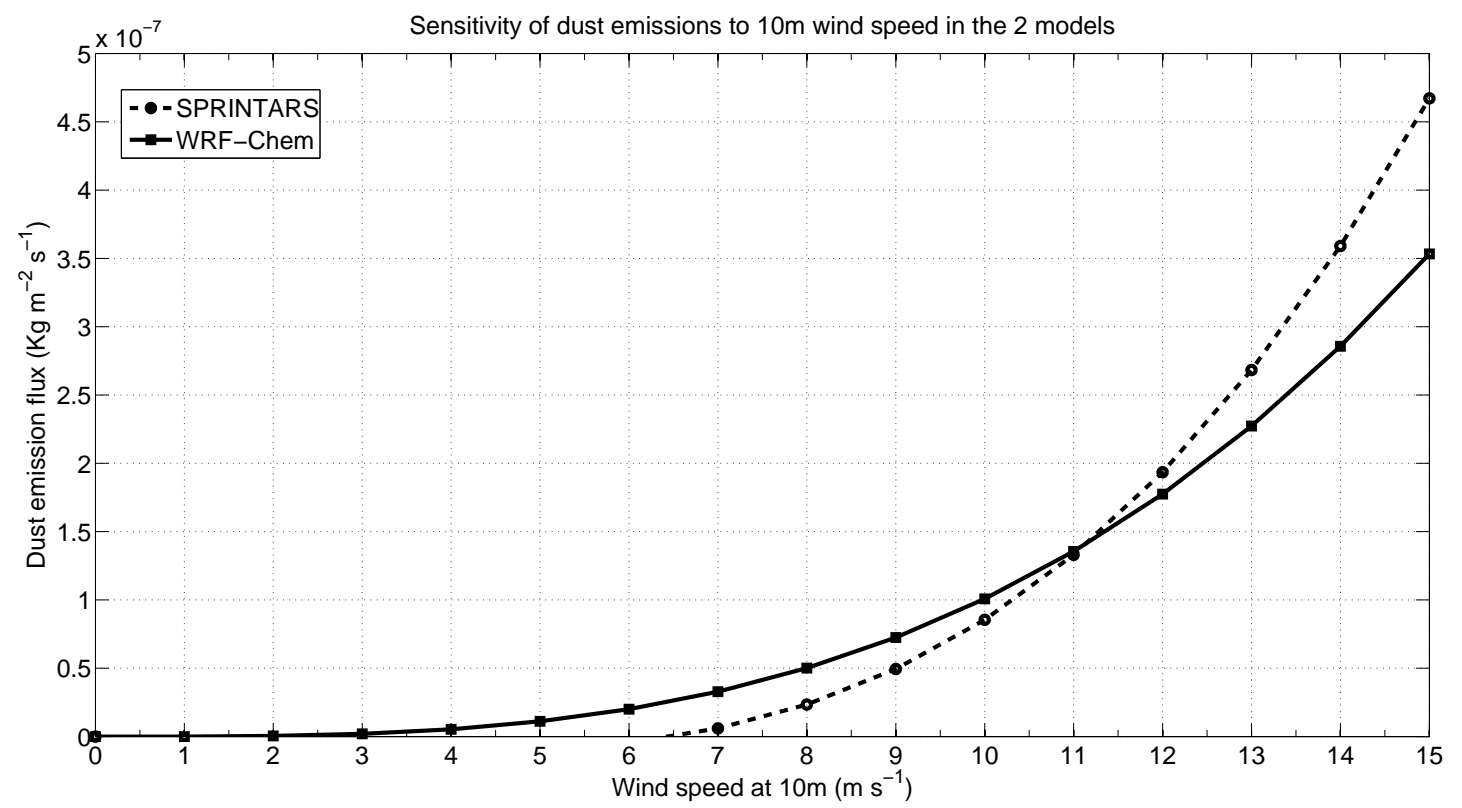

Figure 7: Sensitivity of model-simulated dust emissions to $U_{10}$. Here, dust emissions are calculated by considering particle diameter to be $1.4 \mu \mathrm{m}$, particle density to be $2500 \mathrm{~kg}$ $\mathrm{m}^{-3} \mathrm{SM}=0.001 \mathrm{~m} \mathrm{~m}^{-1}$

plotted as a function of $\mathrm{U}_{10}$, for the particles with diameter $1.4 \mu \mathrm{m}$, density $2500 \mathrm{~kg} \mathrm{~m}^{-3}$ and with a fixed SM value of $0.001 \mathrm{~m} \mathrm{~m}^{-1}$. It may be noted that for both the models WRF-Chem and SPRINTARS, dust emissions are directly proportional to $10 \mathrm{~m}$ wind speeds beyond a threshold value. But, the threshold values for the models differ by a large margin. For WRF-chem, it happens to be around $2 \mathrm{~m} \mathrm{~s}^{-1}$, for the specific values of the aforementioned parameters, while for SPRINTARS it is $6.5 \mathrm{~m} \mathrm{~s}^{-1}$. Also, it could be noted that, for lower $\mathrm{U}_{10}$ values WRF-Chem has higher dust emissions vis-a-vis SPRINTARS, while at higher $\mathrm{U}_{10}$ values $\left(\mathrm{U}_{10}>11 \mathrm{~m} \mathrm{~s}^{-1}\right)$, SPRINTARS show higher dust emissions vis-a-vis WRF-Chem.

During pre-monsoon month, in-general $\mathrm{U}_{10}$ values could go higher than $11 \mathrm{~m} \mathrm{~s}^{-1}$ over the dust source region in these 2 models, which could give rise to higher dust emissions in SPRINTARS vis-a-vis WRF-Chem. While, during Post-monsoon, the $\mathrm{U}_{10}$ magnitudes would in-general be low ( $\mathrm{U}_{10}<$ $11 \mathrm{~m} \mathrm{~s}^{-1}$ ) and thus could cause higher dust emissions in WRF-Chem vis- 

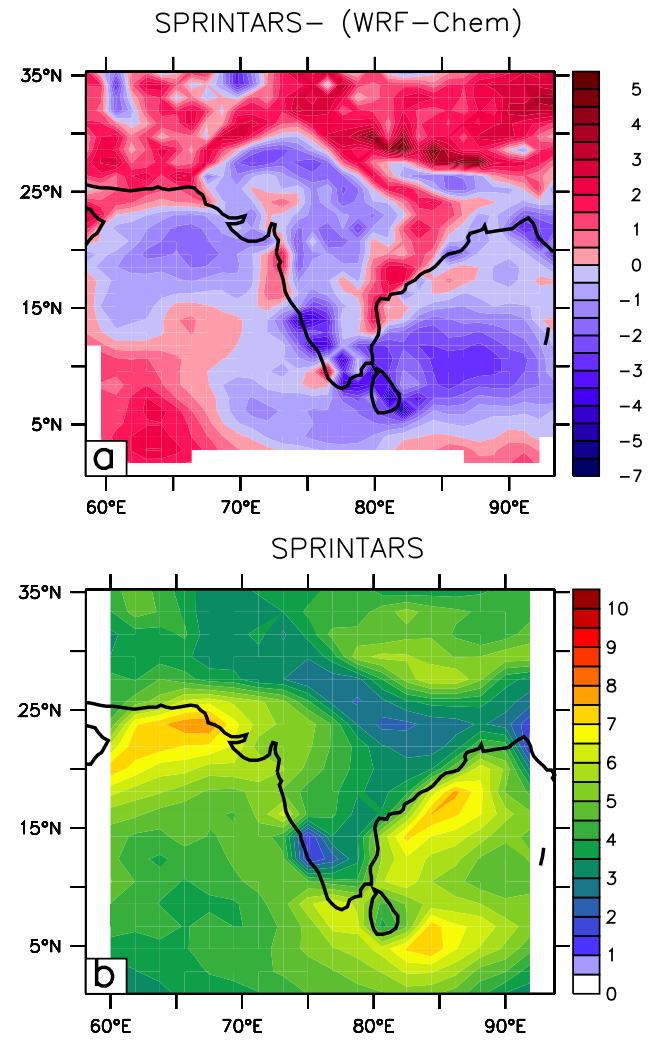

WRF-Chem

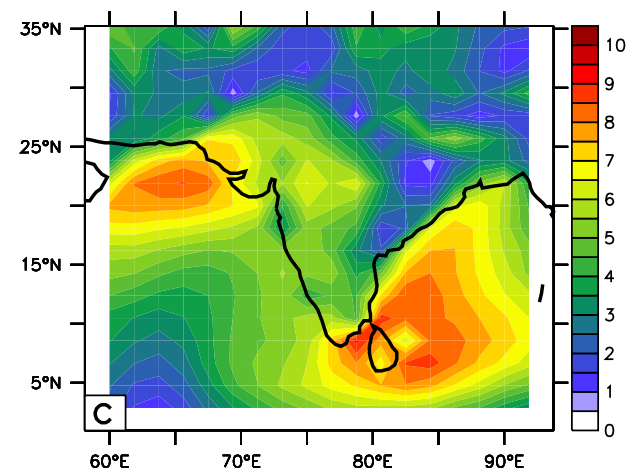

Figure 8: Wind at 10m height from surface during May 2011 a) SPRINTARS-(WRFChem) b) SPRINTARS c) WRF-chem. All values are in $\mathrm{m} \mathrm{s}^{-1}$ 
a-vis SPRINTARS. This to a certain extent explains the differences in dust mass concentration in these models during pre-monsoon and post-monsoon. To understand this further, we have compared the near-surface wind fields in these 2 model simulations for the month of heavy dust loading (i.e. May) and they are presented in Fig.8. It can be seen that (Fig.8a), in general, WRFChem overestimates surface wind speeds over the entire domain. However, SPRINTARS shows higher wind speeds over the semi-arid regions of Sindh and Arabia. These higher winds along with inherent differences in dust production rates in these 2 models, give rise to higher emission fluxes and consequently higher near-surface mass concentrations in SPRINTARS. Also, higher wind speeds over the GP region (Fig.8a) in SPRINTARS simulations vis-a-vis WRF-chem, generates higher dust emissions and thus builds higher dust concentrations. Such a dust source over GP is virtually absent in WRFChem simulations. Similar comparisons were done for SM simulations in both the models (Figure not shown), but the models do not differ much in the simulations of SM. Thus, differences in meteorology $\left(\mathrm{U}_{10}\right)$ and dust emission strategies cause the models to differ in the simulations of dust aerosols. This difference in dust concentrations affects AOD patterns in the two models.

\subsubsection{Role of Refractive Index}

It may be noted that, SPRINTARS (Fig.5g,Fig.5h) fails to simulate the AOD hot spot over GP as seen in satellite products MODIS (Fig.5a,Fig.5b), MISR (Fig.5c,Fig.5d) and in WRF-Chem (Fig.5e,Fig.5f). We examine whether this is related to NSBC. As seen in Fig.3, the spatial pattern of near-surface mass concentrations of $\mathrm{BC}$ aerosols in these 2 model simulations are similar. Both the models capture the BC hot-spot over the GP region during both months. Also, the BC magnitudes over Indian landmass in the 2 model simulations satisfactorily agree with each other with a few exceptions. In spite of such similarities, SPRINTARS does not capture the the expected AOD hot-spot over the GP region. An examination of the optical properties of BC used in these 2 models reveals that WRF-Chem uses $\mathrm{RI}_{B C}=(1.85-0.71 \times \mathrm{i})$ while SPRINTARS employs $\mathrm{RI}_{B C}=(1.75-0.44 \times \mathrm{i})$ which is in agreement with OPAC database. It can be seen that, the imaginary part of the RI for BC in SPRINTARS is $60 \%$ of that in WRF-Chem. So, BC in WRF-Chem has higher absorbing characteristics than in SPRINTARS and OPAC. Thus, due to such differences in RI values, BC in WRF-Chem affects model simulated AOD more significantly than that in SPRINTARS in-spite of having lower mass concentrations (Table 1, Fig.3). Hence, the model simulated AOD dif- 
fers over GP region.

Thus, differences in the AOD simulated by the two models over land appear to be linked with the differences associated with model simulations dust aerosol and the optical properties of BC aerosols within the models.

\subsection{Sea-Salt}

Additionally, we have also studied model simulated sea-salt aerosol distributions (Fig.9). It is to be noted that both the models use identical strategies for the emissions/productions of sea-salt aerosols. Here, as we examine the model simulated near-surface concentrations of sea-salt, we can expect emissions to play a major role in governing these distributions at least over oceans. So, given all these factors, the differences in model-simulated seasalt distributions would mainly arise due to the corresponding differences in the models' meteorology. This would highlight the effect of using purely model-generated meteorology on the aerosol scenario over the oceanic parts of the Indian region. It is seen that during May 2011 both the models (WRFChem, Fig.9a and SPRINTARS, Fig.9c), depict a similar pattern of sea-salt concentrations over the oceanic regions, however WRF-Chem underestimates the magnitudes vis-a-vis SPRINTARS. The regional maxima occur over the northern part of AS and over the western part of the BoB. Over these regions, WRF-chem depicts a mean concentrations around $6-8 \mu \mathrm{g} \mathrm{m}^{-3}$, while SPRINTARS exhibits magnitudes exceeding $10 \mu \mathrm{g} \mathrm{m}^{-3}$. The production of sea-salt over oceans is mainly governed by the interaction of near-surface winds with the water surface. Both the models employ identical formulation for the production of sea-salt aerosols. Thus, to understand the reasons behind such differences in model-simulated sea-salt concentrations, we have again examined simulations of $10 \mathrm{~m}$ winds over the oceanic regions for WRF-Chem (Fig.8c) and SPRINTARS (Fig.8b), for May 2011. We note that regions with higher winds have higher sea-salt concentrations (Fig.8b and Fig.8c). The higher sea-salt magnitudes over the eastern coast in SPRINTARS (vis-a-vis WRF-Chem) appear to be related to higher wind magnitudes over that region in SPRINTARS. Also, the differences in sea-salt concentrations over AS in both the models appear to be loosely linked with the higher winds in SPRINTARS over the northern part of the AS. Additionally, both the models show inland transport of sea-salt mainly due to prevailing winds (ocean to land) during the pre-monsoon months. The landward incursion of sea-salt is higher in WRF-Chem (Fig.9a) than in SPRINTARS (Fig.9c), and 
this could be attributed to the higher wind speeds in WRF-Chem over land during May (Fig.8a).

For October 2011, both the models (WRF-Chem, Fig.9b and SPRINTARS, Fig.9d) exhibit a reduction in sea-salt mass concentrations (similar to dust) which could be mainly attributed to the reduced wind speeds in October vis-a-vis May. The mean concentrations over the source regions are seen to be around 2-3 $\mu \mathrm{g} \mathrm{m}^{-3}$ for WRF-Chem and $3-4 \mu \mathrm{g} \mathrm{m}^{-3}$ for SPRINTARS. Also, the inland-transport of sea-salt which was seen to be very high during May, decreases due to the reversal of the direction of the winds in October (land to ocean). The simulated pattern of sea-salt concentration is similar in the two models the exception being over the Eastern Coast. However, WRF-Chem underestimates the magnitudes of sea-salt mass concentrations vis-a-vis SPRINTARS. The online model overestimates the wind speeds over land and thus transports sea-salts farther into the land, while underestimating the sea-salt production over the oceanic regions. 


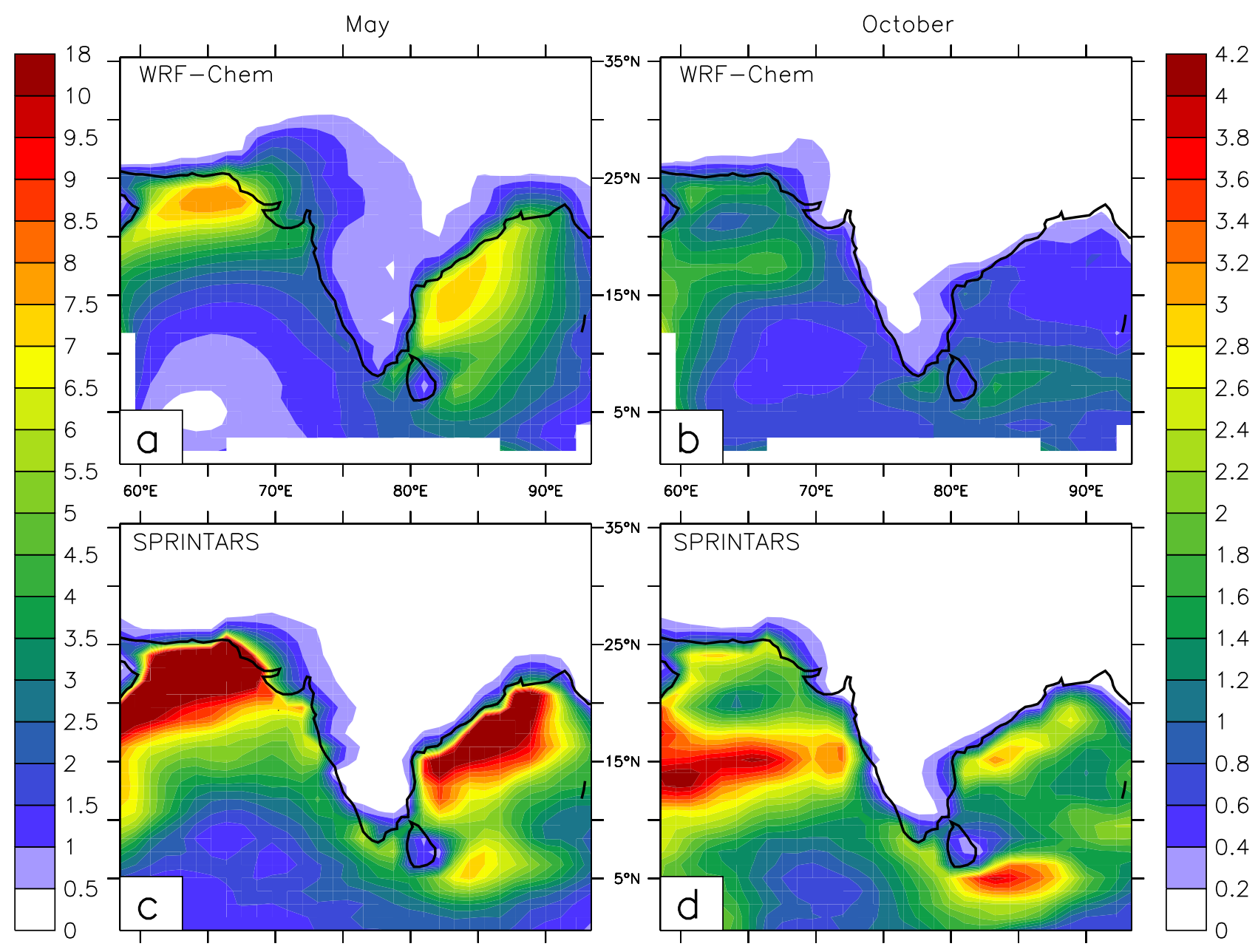

Figure 9: Comparison of model-simulated near-surface sea-salt mass concentration $(\mu \mathrm{g}$ $\mathrm{m}^{-3}$ ) over Indian region during May and October 2011. Left colorbar should be read for May and right one should be read for October 


\section{Conclusions}

The aerosol burden over the south Asian region assumes importance due to its potential impact on Monsoonal rainfall (Lau et al., 2006, Ramanathan et al., 2005), which could affect this densely populated part of the world. In this regard it is imperative to understand some characteristics of this aerosol loading, namely the aerosol species involved, the causes for the production of such species, the lifetime of these short-lived particulates, spatial variation, seasonality, vertical distribution, etc. There are many different models which can simulate such aerosol species. There have been many studies which have simulated the effects of such an aerosol loading on monsoonal rainfall over the region. Nevertheless, it would be worthwhile to validate such models for their representation of the aerosols over India. This validation can be done by comparing the model simulated parameters (mass concentrations, optical depths etc.) with corresponding measurements executed at different observatories spanning the country.

In this study, we compared simulations of aerosols over the Indian region by WRF-Chem and SPRINTARS, with satellite and surface based observational data, for May and October 2011. These models essentially differ in may aspects including a). horizontal resolution b). physical domain c). formulation of meteorological component. This comparison between the models of different kinds and simultaneous evaluation with observations, helped us understand the probable cause for the incorrect simulations of aerosols over the Indian region. We find that both the models underestimate near-surface $\mathrm{BC}$ mass concentrations vis-a-vis measurements done at observatories over 8 stations across India, with the AF ranging from 1.1 to 5.8. Largely, both the models underestimate the observations by similar margins. Both the models have a similar spatial pattern of NSBC with a correlation of 0.92. Keeping in mind such an agreement between $\mathrm{BC}$ simulations by two such models which differ in many aspects, we inspected the $\mathrm{BC}$ emissions scenarios used in these models. The BC emission scenarios used in these 2 models had a very good spatial match with spatial correlation coefficient of 0.97. Such a high spatial $\mathrm{CC}$ in prescribed $\mathrm{BC}$ emissions, could have resulted in high spatial $\mathrm{CC}$ in simulated $\mathrm{BC}$ concentrations. Additionally, it is important to note that the underlying $\mathrm{BC}$ emission inventories used in these two models have a horizontal grid spacing of $0.5^{0} \times 0.5^{0}\left(\right.$ SPRINTARS) and $1^{0} \times 1^{0}$ (WRF-Chem). Since the horizontal grid spacing of the underlying BC emis- 
sion inventories are comparable, they represent all the point sources of BC emissions over Indian region roughly by similar magnitudes. Hence in addition to the similar spatial pattern of $\mathrm{BC}$ emissions the underlying inventories get a match in the magnitudes of $\mathrm{BC}$ emissions as well. This factor plays an important role in giving the similarities in the model simulated NSBC inspite of the differences in the horizontal resolution of the models. We further noted that, WRF-Chem prescribes higher magnitudes of BC emissions visa-vis SPRINTARS over all the observational locations. But, we found that the meteorological parameters in WRF-Chem (low-level winds and boundary layer height) are overestimated vis-a-vis SPRINTARS and the re-analysis dataset MERRA. Thus, even though the models (WRF-Chem and SPRINTARS) differ in many aspects the model simulated NSBC largely agree with each other mainly due the balance between the overestimated meteorological variables in WRF-Chem and lower emissions of BC in SPRINTARS. We further compared the BC emissions inventory used in these two models (GOCART in WRF-Chem and RCP8.5 in SPRINTARS) with three other widely used emission inventories (MACCity, REAS and SAFAR_India).Both GOCART and RCP 8.5 showed a good spatial match with the other global emission inventries. But, our analysis shows that, all the five $\mathrm{BC}$ emission inventories considered in this study underestimate the actual BC emissions over Indian region, by a factor which ranges from 1.5 to 2.9. Such a quantification of underestimations in BC emissions inventory used in WRF-Chem (GOCART), also helped us understand the role played by underestimated emissions and overestimated meteorology in underestimation of NSBC in WRF-Chem.

While BC simulations from the two models are in good agreement, there are significant differences in model simulations of AOD. Both the models underestimate AOD over the region vis-a-vis satellite observational data from MODIS and MISR instruments, for both the months of the model simulations. SPRINTARS AOD values are closer to observational AOD magnitudes, than in WRF-Chem. Nevertheless, WRF-Chem significantly replicates the pattern of satellite AOD with a spatial correlation coefficient around 0.8. Dust also is a significant contributor to aerosol loading over the Indian region. An examination of dust simulations by the models reveals that the models differ significantly in simulating dust over the Indian region. The main differences occur due to differences in meteorology and dust emission formulations within the models. Dust aerosol looks to dominate the composite AOD in 
SPRINTARS simulations. These differences in dust concentrations appears to be the major cause of differences in model simulated AOD especially over Sindh and parts of GP. Models also differ in prescribing the optical properties for BC aerosol. WRF-Chem employs BC absorption 1.6 times higher vis-a-vis SPRINTARS. This results in differences in AOD mainly over BC hot-spots like GP. Thus while the models agree with each other in simulating near-surface BC concentrations, they differ in simulating AOD over the region, the main causes of which could be the differences in meteorology, dust emissions strategy and RI values for BC.

Additionally, we also examined model simulated concentrations of sea-salt aerosols. While both the models show a similar spatial pattern of sea-salt concentration, WRF-Chem underestimated the magnitude of sea-salt visa-vis SPRINTARS. Also, it showed a greater inland transport of sea-salt vis-a-vis SPRINTARS. As the models employ the same strategy for sea-salt emissions, the differences in sea-salt aerosols are related to the differences in near-surface winds over the region.

This model inter-comparison and evaluation study augments the current knowledge regarding the state of aerosol simulating models over Indian region. While there are a few studies (Nair et al., 2012, Moorthy et al., 2013, Pan et al., 2015, Govardhan et al., 2015) available regarding the performances of such models, this study inter-compares and evaluates the 2 different kinds of models, for an identical period, which does not overlap with that in previous studies. Such an exercise highlights the role played by meteorology and emissions' inventories in affecting the aerosol simulations in such models. It indicates that emission scenarios for anthropogenic aerosols and emission formulation for natural aerosol need to be re-examined and improved. However, more such intercomparisons (and subsequent modifications in the models) are also needed to be done for longer periods and over different regions to reduce the uncertainties in the model predictions.

\section{References}

Babu, S.S., Manoj, M.R., Moorthy, K.K., Gogoi, M.M., Nair, V.S., Kompalli, S.K., Satheesh, S.K., Niranjan, K., Ramagopal, K., Bhuyan, P.K., Singh, D., 2013. Trends in aerosol optical depth over Indian region: Potential causes and impact in- 
dicators. Journal of Geophysical Research: Atmospheres 118, 11,794-11,806. URL: http://dx.doi.org/10.1002/2013JD020507, doi:10.1002/2013JD020507.

Babu, S.S., Moorthy, K.K., Manchanda, R.K., Sinha, P.R., Satheesh, S.K., Vajja, D.P., Srinivasan, S., Kumar, V.H.A., 2011. Free tropospheric black carbon aerosol measurements using high altitude balloon: Do bc layers build their own homes up in the atmosphere? Geophysical Research Letters 38. URL: http://dx.doi.org/10.1029/2011GL046654, doi:10.1029/2011GL046654.

Bibi, H., Alam, K., Chishtie, F., Bibi, S., Shahid, I., Blaschke, T., 2015. Intercomparison of modis, misr, omi, and $\{$ CALIPSO $\}$ aerosol optical depth retrievals for four locations on the indo-gangetic plains and validation against \{AERONET\} data. Atmospheric Environment 111, 113 - 126. URL: http://www.sciencedirect.com/science/article/pii/S1352231015300169, doi:http://dx.doi.org/10.1016/j.atmosenv.2015.04.013.

Bollasina, M.A., Ming, Y., Ramaswamy, V., 2011. Anthropogenic aerosols and the weakening of the south Asian summer monsoon. science 334, 502-505. doi:10.1126/science.1204994.

Chakraborty, A., Satheesh, S.K., Nanjundiah, R.S., Srinivasan, J., 2004. Impact of absorbing aerosols on the simulation of climate over the Indian region in an atmospheric general circulation model. Annales Geophysicae 22, 1421-1434. doi:10.5194/angeo-22-1421-2004.

Cherian, R., Venkataraman, C., Quaas, J., Ramachandran, S., . Gcm simulations of anthropogenic aerosol-induced changes in aerosol extinction, atmospheric heating and precipitation over India. Journal of Geophysical Research: Atmospheres 118, 2938-2955. URL: http://dx.doi.org/10.1002/jgrd.50298, doi:10.1002/jgrd.50298.

Chin, M., Diehl, T., Dubovik, O., Eck, T.F., Holben, B.N., Sinyuk, A., Streets, D.G., 2009. Light absorption by pollution, dust, and biomass burning aerosols: a global model study and evaluation with aeronet measurements. Annales Geophysicae 27, 3439-3464. URL: http://www . ann-geophys.net/27/3439/2009/, doi:10.5194/angeo-27-3439-2009. 
Chin, M., Ginoux, P., Kinne, S., Torres, O., Holben, B.N., Duncan, B.N., Martin, R.V., Logan, J.A., Higurashi, A., Nakajima, T., 2002. Tropospheric aerosol optical thickness from the gocart model and comparisons with satellite and sun photometer measurements. Journal of the Atmospheric Sciences 59, 461-483. doi:10.1175/15200469(2002)059;0461:TAOTFT ¿2.0.CO;2.

Choudhry, P., Misra, A., Tripathi, S.N., 2012. Study of modis derived aod at three different locations in the indo gangetic plain: Kanpur, gandhi college and nainital. Annales Geophysicae 30, 1479-1493. URL: http://www. ann-geophys.net/30/1479/2012/, doi:10.5194/angeo-30-1479-2012.

Cooke, W., Liousse, C., Cachier, H., Feichter, J., 1999. Construction of a $1 \times 1$ fossil fuel emission data set for carbonaceous aerosol and implementation and radiative impact in the echam4 model. Journal of Geophysical Research 104, 22137-22. doi:10.1029/1999JD900187.

Diehl, T., Heil, A., Chin, M., Pan, X., Streets, D., Schultz, M., Kinne, S., 2012. Anthropogenic, biomass burning, and volcanic emissions of black carbon, organic carbon, and $\mathrm{so}_{2}$ from 1980 to 2010 for hindcast model experiments. Atmospheric Chemistry and Physics Discussions 12, 24895-24954. URL: http://www. atmos-chem-phys-discuss.net/12/24895/2012/, doi:10.5194/acpd-12-24895-2012.

Emmons, L.K., Walters, S., Hess, P.G., Lamarque, J.F., Pfister, G.G., Fillmore, D., Granier, C., Guenther, A., Kinnison, D., Laepple, T., Orlando, J., Tie, X., Tyndall, G., Wiedinmyer, C., Baughcum, S.L., Kloster, S., 2010. Description and evaluation of the model for ozone and related chemical tracers, version 4 (mozart-4). Geoscientific Model Development 3, 43-67. doi:10.5194/gmd-3-43-2010.

Freitas, S.R., Longo, K.M., Alonso, M.F., Pirre, M., Marecal, V., Grell, G., Stockler, R., Mello, R.F., Sánchez Gácita, M., 2011. Prep-chem-src 1.0: a preprocessor of trace gas and aerosol emission fields for regional and global atmospheric chemistry models. Geoscientific Model Development 4, 419-433. URL: http://www.geosci-model-dev.net/4/419/2011/, doi:10.5194/gmd-4-419-2011. 
Ganguly, D., Ginoux, P., Ramaswamy, V., Winker, D.M., Holben, B.N., Tripathi, S.N., 2009. Retrieving the composition and concentration of aerosols over the indo-gangetic basin using caliop and aeronet data. Geophysical Research Letters 36. URL: http://dx.doi .org/10.1029/2009GL038315, doi:10.1029/2009GL038315.

Gautam, R., Hsu, N.C., Lau, W.K.M., Yasunari, T.J., 2013. Satellite observations of desert dust-induced himalayan snow darkening. Geophysical Research Letters 40, 988-993. URL: http://dx.doi.org/10.1002/grl.50226, doi:10.1002/grl.50226.

Ginoux, P., Chin, M., Tegen, I., Prospero, J.M., Holben, B., Dubovik, O., Lin, S.J., 2001. Sources and distributions of dust aerosols simulated with the gocart model. Journal of Geophysical Research: Atmospheres 106, 20255-20273. URL: http://dx.doi.org/10.1029/2000JD000053, doi:10.1029/2000JD000053.

Goto, D., Takemura, T., Nakajima, T., Badarinath, K., 2011. Global aerosol model-derived black carbon concentration and single scattering albedo over Indian region and its comparison with ground observations. Atmospheric Environment 45, 3277 - 3285. URL: http://www. sciencedirect.com/science/article/pii/S1352231011002974, doi:http://dx.doi.org/10.1016/j.atmosenv.2011.03.037.

Govardhan, G., Nanjundiah, R., Satheesh, S., Krishnamoorthy, K., Kotamarthi, V., 2015. Performance of WRF-Chem over Indian region: Comparison with measurements. Journal of Earth System Science 124, 875-896. URL: http://dx.doi.org/10.1007/s12040-015-0576-7, doi:10.1007/s12040-015-0576-7.

Granier, C., Bessagnet, B., Bond, T., DAngiola, A., Denier van der Gon, H., Frost, G., Heil, A., Kaiser, J., Kinne, S., Klimont, Z., Kloster, S., Lamarque, J.F., Liousse, C., Masui, T., Meleux, F., Mieville, A., Ohara, T., Raut, J.C., Riahi, K., Schultz, M., Smith, S., Thompson, A., van Aardenne, J., van der Werf, G., van Vuuren, D., 2011. Evolution of anthropogenic and biomass burning emissions of air pollutants at global and regional scales during the 1980-2010 period. Climatic Change 109, 163-190. URL: http://dx.doi.org/10.1007/s10584-011-0154-1, doi:10.1007/s10584-011-0154-1. 
Grell, G.A., Peckham, S.E., Schmitz, R., McKeen, S.A., Frost, G., Skamarock, W.C., Eder, B., 2005. Fully coupled online chemistry within the $\{\mathrm{WRF}\}$ model. Atmospheric Environment 39, 6957 - 6975. URL: http://www.sciencedirect.com/science/article/pii/S1352231005003560, doi:http://dx.doi.org/10.1016/j.atmosenv.2005.04.027.

Haywood, J., Boucher, O., 2000. Estimates of the direct and indirect radiative forcing due to tropospheric aerosols: A review. Reviews of Geophysics 38, 513-543. doi:10.1029/1999RG000078.

Haywood, J.M., Ramaswamy, V., 1998. Global sensitivity studies of the direct radiative forcing due to anthropogenic sulfate and black carbon aerosols. Journal of Geophysical Research: Atmospheres 103, 6043-6058. doi:10.1029/97JD03426.

Henriksson, S.V., Laaksonen, A., Kerminen, V.M., Räisänen, P., Järvinen, H., Sundström, A.M., de Leeuw, G., 2011. Spatial distributions and seasonal cycles of aerosols in India and china seen in global climate-aerosol model. Atmospheric Chemistry and Physics 11, 7975-7990. URL: http://www .atmos-chem-phys .net/11/7975/2011/, doi:10.5194/acp-11-7975-2011.

Janjić, Z.I., 2002. Nonsingular implementation of the mellor-yamada level 2.5 scheme in the ncep meso model. NCEP Office Note 437, 61.

Janssen, N., Hoek, G., Simic-Lawson, M., Fischer, P., Van Bree, L., Ten Brink, H., Keuken, M., Atkinson, R.W., Anderson, H.R., Brunekreef, B., et al., 2011. Black carbon as an additional indicator of the adverse health effects of airborne particles compared with pm10 and pm2. 5. Environ Health Perspect 119, 1691-1699.

Jena, C., Ghude, S.D., Beig, G., Chate, D., Kumar, R., Pfister, G., Lal, D., Surendran, D.E., Fadnavis, S., van der A, R., 2015. Inter-comparison of different $\{$ NOX $\}$ emission inventories and associated variation in simulated surface ozone in Indian region. Atmospheric Environment 117, 61 - 73. URL: http://www.sciencedirect.com/science/article/pii/S1352231015301989, doi:http://dx.doi.org/10.1016/j.atmosenv.2015.06.057. 
Jethva, H., Satheesh, S.K., Srinivasan, J., 2007a. Assessment of second-generation modis aerosol retrieval (collection 005) at kanpur, India. Geophysical Research Letters 34, n/a-n/a. URL: http://dx.doi.org/10.1029/2007GL029647, doi:10.1029/2007GL029647. 119802.

Jethva, H., Satheesh, S.K., Srinivasan, J., 2007b. Evaluation of moderate-resolution imaging spectroradiometer (modis) collection 004 (c004) aerosol retrievals at kanpur, indo-gangetic basin. Journal of Geophysical Research: Atmospheres 112, n/a-n/a. URL: http://dx.doi.org/10.1029/2006JD007929, doi:10.1029/2006JD007929. d14216.

Kahn, R.A., Garay, M.J., Nelson, D.L., Yau, K.K., Bull, M.A., Gaitley, B.J., Martonchik, J.V., Levy, R.C., 2007. Satellite-derived aerosol optical depth over dark water from misr and modis: Comparisons with aeronet and implications for climatological studies. Journal of Geophysical Research: Atmospheres 112. doi:10.1029/2006JD008175.

Kaufman, Y.J., Tanré, D., Boucher, O., et al., 2002. A satellite view of aerosols in the climate system. Nature 419, 215-223. doi:10.1038/nature01091.

King, M.D., Kaufman, Y.J., Tanr, D., Nakajima, T., 1999. Remote sensing of tropospheric aerosols from space: Past, present, and future. Bulletin of the American Meteorological Society 80, 2229-2259. doi:10.1175/15200477(1999)080;2229:RSOTAF ¿2.0.CO;2.

Krzyzanowski, M., Kuna-Dibbert, B., Schneider, J., et al., 2005. Health effects of transport-related air pollution. World Health Organization Copenhagen, Denmark.

Kumar, R., Naja, M., Pfister, G.G., Barth, M.C., Brasseur, G.P., 2011. Simulations over south Asia using the weather research and forecasting model with chemistry (WRF-Chem): set-up and meteorological evaluation. Geoscientific Model Development Discussions 4, 3067-3125. doi:10.5194/gmdd-4-3067-2011.

Kumar, R., Naja, M., Pfister, G.G., Barth, M.C., Wiedinmyer, C., Brasseur, G.P., 2012. Simulations over south Asia using the weather research 
and forecasting model with chemistry (WRF-Chem): chemistry evaluation and initial results. Geoscientific Model Development 5, 619-648. doi:10.5194/gmd-5-619-2012.

Lamarque, J.F., Bond, T.C., Eyring, V., Granier, C., Heil, A., Klimont, Z., Lee, D., Liousse, C., Mieville, A., Owen, B., Schultz, M.G., Shindell, D., Smith, S.J., Stehfest, E., Van Aardenne, J., Cooper, O.R., Kainuma, M., Mahowald, N., McConnell, J.R., Naik, V., Riahi, K., van Vuuren, D.P., 2010. Historical (1850-2000) gridded anthropogenic and biomass burning emissions of reactive gases and aerosols: methodology and application. Atmospheric Chemistry and Physics 10, 7017-7039. URL: http://www .atmos-chem-phys .net/10/7017/2010/, doi:10.5194/acp-10-7017-2010.

Lau, K., Kim, M., Kim, K., 2006. Asian summer monsoon anomalies induced by aerosol direct forcing: the role of the tibetan plateau. Climate Dynamics 26, 855-864. doi:10.1007/s00382-006-0114-z.

Lau, W.K.M., Kim, M.K., Kim, K.M., Lee, W.S., 2010. Enhanced surface warming and accelerated snow melt in the himalayas and tibetan plateau induced by absorbing aerosols. Environmental Research Letters 5, 025204. URL: http://stacks.iop.org/1748-9326/5/i=2/a=025204.

Lelieveld, J., Crutzen, P.J., Ramanathan, V., Andreae, M.O., Brenninkmeijer, C.A.M., Campos, T., Cass, G.R., Dickerson, R.R., Fischer, H., de Gouw, J.A., Hansel, A., Jefferson, A., Kley, D., de Laat, A.T.J., Lal, S., Lawrence, M.G., Lobert, J.M., Mayol-Bracero, O.L., Mitra, A.P., Novakov, T., Oltmans, S.J., Prather, K.A., Reiner, T., Rodhe, H., Scheeren, H.A., Sikka, D., Williams, J., 2001. The Indian ocean experiment: Widespread air pollution from south and southeast Asia. Science 291, 1031-1036. doi:10.1126/science.1057103.

Levy, R.C., Remer, L.A., Kleidman, R.G., Mattoo, S., Ichoku, C., Kahn, R., Eck, T.F., 2010. Global evaluation of the collection 5 modis darktarget aerosol products over land. Atmospheric Chemistry and Physics Discussions 10, 14815-14873. doi:10.5194/acpd-10-14815-2010.

Lohmann, U., Feichter, J., 2005. Global indirect aerosol effects: a review. Atmospheric Chemistry and Physics 5, 715-737. doi:10.5194/acp-5-7152005. 
Lohmann, U., Lesins, G., 2002. Stronger constraints on the anthropogenic indirect aerosol effect. Science 298, 1012-1015. doi:10.1126/science.1075405.

Misra, A., Jayaraman, A., Ganguly, D., 2015. Validation of version 5.1 modis aerosol optical depth (deep blue algorithm and dark target approach) over a semi-arid location in western India. Aerosol and Air Quality Research 15, 252-262. doi:10.4209/aaqr.2014.01.0004.

Mlawer, E.J., Taubman, S.J., Brown, P.D., Iacono, M.J., Clough, S.A., 1997. Radiative transfer for inhomogeneous atmospheres: Rrtm, a validated correlated-k model for the longwave. Journal of Geophysical Research: Atmospheres 102, 16663-16682. doi:10.1029/97JD00237.

Moorthy, K., Satheesh, S., Babu, S., Dutt, C., 2008. Integrated campaign for aerosols, gases and radiation budget (icarb): An overview. Journal of Earth System Science 117, 243-262. doi:10.1007/s12040-008-0029-7.

Moorthy, K.K., Beegum, S.N., Srivastava, N., Satheesh, S., Chin, M., Blond, N., Babu, S.S., Singh, S., 2013. Performance evaluation of chemistry transport models over India. Atmospheric Environment 71, 210 - 225. doi:10.1016/j.atmosenv.2013.01.056.

Moorthy, K.K., Nair, V.S., Babu, S.S., Satheesh, S.K., 2009. Spatial and vertical heterogeneities in aerosol properties over oceanic regions around India: Implications for radiative forcing. Quarterly Journal of the Royal Meteorological Society 135, 2131-2145. doi:10.1002/qj.525.

Moorthy, K.K., Satheesh, S., 2011. Black carbon aerosols over India. UNEPs Black Carbon e-Bulletin 3, 1-3.

More, S., Kumar, P.P., Gupta, P., Devara, P., Aher, G., 2013. Comparison of aerosol products retrieved from aeronet, microtops and modis over a tropical urban city, pune, India. Aerosol and Air Quality Research 13, 107-121. doi:10.4209/aaqr.2012.04.0102.

Myhre, G., 2009. Consistency between satellite-derived and modeled estimates of the direct aerosol effect. Science 325, 187-190. doi:10.1126/science.1174461.

Nair, V., Babu, S.S., Moorthy, K.K., Sharma, A., Marinoni, A., ., A., 2013. Black carbon aerosols over the himalayas: 
direct and surface albedo forcing.

Tellus B 65 .

URL: http://www.tellusb.net/index.php/tellusb/article/view/19738.

Nair, V.S., Solmon, F., Giorgi, F., Mariotti, L., Babu, S.S., Moorthy, K.K., 2012. Simulation of south Asian aerosols for regional climate studies. Journal of Geophysical Research: Atmospheres 117. doi:10.1029/2011JD016711.

Ohara, T., Akimoto, H., Kurokawa, J., Horii, N., Yamaji, K., Yan, X., Hayasaka, T., 2007. An Asian emission inventory of anthropogenic emission sources for the period 1980-2020. Atmospheric Chemistry and Physics 7, 4419-4444. URL: http://www.atmos-chem-phys.net/7/4419/2007/, doi:10.5194/acp-7-4419-2007.

Olivier, J.G.J., Bouwman, A., Berdowski, J., Veldt, C., Bloos, J., Visschedijk, A., Zandveld, P., Haverlag, J., et al., 1996. Description of edgar version 2.0: A set of global emission inventories of greenhouse gases and ozone-depleting substances for all anthropogenic and most natural sources on a per country basis and on 1 degree $\mathrm{x} 1$ degree grid .

Pan, X., Chin, M., Gautam, R., Bian, H., Kim, D., Colarco, P.R., Diehl, T.L., Takemura, T., Pozzoli, L., Tsigaridis, K., Bauer, S., Bellouin, N., 2015. A multi-model evaluation of aerosols over south Asia: common problems and possible causes. Atmospheric Chemistry and Physics 15, 5903-5928. URL: http://www .atmos-chem-phys.net/15/5903/2015/, doi:10.5194/acp-15-5903-2015.

Porch, W., Chylek, P., Dubey, M., Massie, S., 2007. Trends in aerosol optical depth for cities in India. Atmospheric Environment 41, 7524-7532. URL: http://www. sciencedirect.com/science/article/pii/S1352231007004931, doi:http://dx.doi.org/10.1016/j.atmosenv.2007.05.055.

Qian, Y., Flanner, M.G., Leung, L.R., Wang, W., 2011. Sensitivity studies on the impacts of tibetan plateau snowpack pollution on the Asian hydrological cycle and monsoon climate. Atmospheric Chemistry and Physics 11, 1929-1948. URL: http://www.atmos-chem-phys.net/11/1929/2011/, doi:10.5194/acp-11-1929-2011.

Ramachandran, S., Kedia, S., Srivastava, R., 2012. Aerosol optical depth trends over different regions of India. Atmospheric Environment 49, 338 - 347. URL: 
http://www.sciencedirect.com/science/article/pii/S1352231011011800, doi:http://dx.doi.org/10.1016/j.atmosenv.2011.11.017.

Ramanathan, V., Chung, C., Kim, D., Bettge, T., Buja, L., Kiehl, J., Washington, W., Fu, Q., Sikka, D., Wild, M., 2005. Atmospheric brown clouds: Impacts on south Asian climate and hydrological cycle. Proceedings of the National Academy of Sciences of the United States of America 102, 5326-5333. doi:10.1073/pnas.0500656102.

Ramanathan, V., Crutzen, P.J., Lelieveld, J., Mitra, A.P., Althausen, D., Anderson, J., Andreae, M.O., Cantrell, W., Cass, G.R., Chung, C.E., Clarke, A.D., Coakley, J.A., Collins, W.D., Conant, W.C., Dulac, F., Heintzenberg, J., Heymsfield, A.J., Holben, B., Howell, S., Hudson, J., Jayaraman, A., Kiehl, J.T., Krishnamurti, T.N., Lubin, D., McFarquhar, G., Novakov, T., Ogren, J.A., Podgorny, I.A., Prather, K., Priestley, K., Prospero, J.M., Quinn, P.K., Rajeev, K., Rasch, P., Rupert, S., Sadourny, R., Satheesh, S.K., Shaw, G.E., Sheridan, P., Valero, F.P.J., 2001. Indian ocean experiment: An integrated analysis of the climate forcing and effects of the great indo-asian haze. Journal of Geophysical Research: Atmospheres 106, 28371-28398. doi:10.1029/2001JD900133.

Ravi Kiran, V., Rajeevan, M., Vijaya Bhaskara Rao, S., Prabhakara Rao, N., 2009. Analysis of variations of cloud and aerosol properties associated with active and break spells of Indian summer monsoon using modis data. Geophysical Research Letters 36. doi:10.1029/2008GL037135.

Reddy, M.S., Boucher, O., Venkataraman, C., Verma, S., Lon, J.F., Bellouin, N., Pham, M., 2004. General circulation model estimates of aerosol transport and radiative forcing during the Indian ocean experiment. Journal of Geophysical Research: Atmospheres 109, n/a-n/a. URL: http://dx.doi.org/10.1029/2004JD004557, doi:10.1029/2004JD004557.

Remer, L.A., Kaufman, Y., Tanré, D., Mattoo, S., Chu, D., Martins, J., Li, R.R., Ichoku, C., Levy, R., Kleidman, R., et al., 2005. The modis aerosol algorithm, products, and validation. Journal of the Atmospheric Sciences 62, 947-973. doi:10.1175/JAS3385.1.

Riahi, K., Grbler, A., Nakicenovic, N., 2007. Scenarios of long-term socio-economic and environmental development under climate stabiliza- 
tion. Technological Forecasting and Social Change 74, 887 - 935. URL: http://www.sciencedirect.com/science/article/pii/S0040162506001387, doi:http://dx.doi.org/10.1016/j.techfore.2006.05.026. greenhouse Gases Integrated Assessment.

Sahu, S.K., Beig, G., Sharma, C., 2008. Decadal growth of black carbon emissions in India. Geophysical Research Letters 35, n/a-n/a. URL: http://dx.doi.org/10.1029/2007GL032333, doi:10.1029/2007GL032333. 102807.

Sanap, S., Ayantika, D., Pandithurai, G., Niranjan, K., 2014. Assessment of the aerosol distribution over Indian subcontinent in \{CMIP5\} models. Atmospheric Environment 87, 123 - 137. URL: http://www.sciencedirect.com/science/article/pii/S1352231014000260, doi:http://dx.doi.org/10.1016/j.atmosenv.2014.01.017.

Schultz, M., Backman, L., Balkanski, Y., Bjoerndalsaeter, S., Brand, R., Burrows, J., Dalsoeren, S., de Vasconcelos, M., Grodtmann, B., Hauglustaine, D., et al., 2007. Reanalysis of the tropospheric chemical composition over the past 40 years (retro)-a long-term global modeling study of tropospheric chemistry. Final Report, Jülich/Hamburg, Germany 2007.

Skamarock, W., Klemp, J., Dudhia, J., Gill, D., Barker, D., Duda, M., Huang, X., Wang, W., Powers, J., 2008. A description of the advanced research wrf version 3. NCAR technical note NCAR/TN/u2013475.

Smirnova, T.G., Brown, J., M.Benjamin, S.G., 1997. Performance of different soil model configurations in simulating ground surface temperature and surface fluxes. Monthly Weather Review 125, 1870-1884. doi:10.1175/1520-0493(1997)125¡1870:PODSMC ¿2.0.CO;2.

Smirnova, T.G., Brown, J.M., Benjamin, S.G., Kim, D., 2000. Parameterization of cold-season processes in the maps land-surface scheme. Journal of Geophysical Research: Atmospheres 105, 4077-4086. doi:10.1029/1999JD901047.

Takemura, T., 2012. Distributions and climate effects of atmospheric aerosols from the preindustrial era to 2100 along representative concentration pathways (rcps) simulated using the global aerosol model sprintars. Atmospheric Chemistry and Physics 12, 11555-11572. URL: 
http://www. atmos-chem-phys.net/12/11555/2012/, doi:10.5194/acp12-11555-2012.

Takemura, T., Egashira, M., Matsuzawa, K., Ichijo, H., O'ishi, R., Abe-Ouchi, A., 2009. A simulation of the global distribution and radiative forcing of soil dust aerosols at the last glacial maximum. Atmospheric Chemistry and Physics 9, 3061-3073. URL: http://www . atmos-chem-phys . net/9/3061/2009/, doi:10.5194/acp-93061-2009.

Takemura, T., Nozawa, T., Emori, S., Nakajima, T.Y., Nakajima, T., 2005. Simulation of climate response to aerosol direct and indirect effects with aerosol transport-radiation model. Journal of Geophysical Research: Atmospheres 110. doi:10.1029/2004JD005029.

Takemura, T., Okamoto, H., Maruyama, Y., Numaguti, A., Higurashi, A., Nakajima, T., 2000. Global three-dimensional simulation of aerosol optical thickness distribution of various origins. Journal of Geophysical Research: Atmospheres 105, 17853-17873. doi:10.1029/2000JD900265.

Thompson, G., Rasmussen, R.M., Manning, K., 2004. Explicit forecasts of winter precipitation using an improved bulk microphysics scheme. part i: Description and sensitivity analysis. Monthly Weather Review 132, 519542. doi:10.1175/1520-0493(2004)132;0519:EFOWPU;2.0.CO;2.

Twomey, S., 1977. The influence of pollution on the shortwave albedo of clouds. Journal of the Atmospheric Sciences 34, 1149-1152. doi:10.1175/1520-0469(1977)034¡1149:TIOPOT¿2.0.CO;2.

van der Werf, G.R., Randerson, J.T., Giglio, L., Collatz, G.J., Mu, M., Kasibhatla, P.S., Morton, D.C., DeFries, R.S., Jin, Y., van Leeuwen, T.T., 2010. Global fire emissions and the contribution of deforestation, savanna, forest, agricultural, and peat fires (19972009). Atmospheric Chemistry and Physics 10, 11707-11735. URL: http://www.atmos-chem-phys.net/10/11707/2010/, doi:10.5194/acp10-11707-2010.

Wild, O., Zhu, X., Prather, M., 2000. Fast-j: Accurate simulation of inand below-cloud photolysis in tropospheric chemical models. Journal of Atmospheric Chemistry 37, 245-282. doi:10.1023/A:1006415919030. 
Yasunari, T.J., Bonasoni, P., Laj, P., Fujita, K., Vuillermoz, E., Marinoni, A., Cristofanelli, P., Duchi, R., Tartari, G., Lau, K.M., 2010. Estimated impact of black carbon deposition during pre-monsoon season from nepal climate observatory pyramid data and snow albedo changes over himalayan glaciers. Atmospheric Chemistry and Physics 10, 6603-6615. URL: http://www.atmos-chem-phys.net/10/6603/2010/, doi:10.5194/acp-10-6603-2010.

Yu, H., Kaufman, Y.J., Chin, M., Feingold, G., Remer, L.A., Anderson, T.L., Balkanski, Y., Bellouin, N., Boucher, O., Christopher, S., DeCola, P., Kahn, R., Koch, D., Loeb, N., Reddy, M.S., Schulz, M., Takemura, T., Zhou, M., 2006. A review of measurement-based assessments of the aerosol direct radiative effect and forcing. Atmospheric Chemistry and Physics 6, 613-666. doi:10.5194/acp-6-613-2006.

Zhang, G.J., McFarlane, N.A., 1995. Sensitivity of climate simulations to the parameterization of cumulus convection in the Canadian climate centre general circulation model. Atmosphere-ocean 33, 407-446. doi:10.1080/07055900.1995.9649539.

Zhang, J., Christopher, S.A., Remer, L.A., Kaufman, Y.J., 2005. Shortwave aerosol radiative forcing over cloud-free oceans from terra: 2. seasonal and global distributions. Journal of Geophysical Research: Atmospheres 110. doi:10.1029/2004JD005009. 